Article

\title{
Slope Failure in a Period of Increased Landslide Activity: Sennwald Rock Avalanche, Switzerland
}

\author{
Selçuk Aksay ${ }^{1,2,3, * \mathbb{C}}$, Susan Ivy-Ochs ${ }^{1,2}$, Kristina Hippe ${ }^{2}$, Lorenz Grämiger ${ }^{1}{ }^{\mathbb{D}}$ and Christof Vockenhuber ${ }^{2}$ \\ 1 Department of Earth Sciences, ETH Zürich, Sonneggstrasse 5, CH-8092 Zürich, Switzerland; \\ ivy@phys.ethz.ch (S.I.-O.); graemiger.lorenz@gmail.com (L.G.) \\ 2 Laboratory of Ion Beam Physics, ETH Zürich, Otto-Stern-Weg 5, CH-8093 Zürich, Switzerland; \\ hippe@phys.ethz.ch (K.H.); cvockenh@ethz.ch (C.V.) \\ 3 Soil Geography and Landscape Group, Wageningen University, P.O. Box 47, \\ NL-6700 AA Wageningen, The Netherlands \\ * Correspondence: selcuk.aksay@wur.nl; Tel.: +31-317-485-465
}

check for updates

Citation: Aksay, S.; Ivy-Ochs, S.; Hippe, K.; Grämiger, L.; Vockenhuber, C. Slope Failure in a Period of Increased Landslide Activity: Sennwald Rock Avalanche, Switzerland. Geosciences 2021, 11, 331. https://doi.org/10.3390/ geosciences11080331

Academic Editors: Ángel Rodés and Jesús Martínez-Frías

Received: 7 July 2021

Accepted: 2 August 2021

Published: 5 August 2021

Publisher's Note: MDPI stays neutral with regard to jurisdictional claims in published maps and institutional affiliations.

Copyright: (c) 2021 by the authors. Licensee MDPI, Basel, Switzerland. This article is an open access article distributed under the terms and conditions of the Creative Commons Attribution (CC BY) license (https:// creativecommons.org/licenses/by/ $4.0 /)$.

\begin{abstract}
The Säntis nappe is a complex fold-and-thrust structure in eastern Switzerland, consisting of numerous tectonic discontinuities and a range of hillslopes prone to landsliding and large slope failures that modify the topography irreversibly. A slope failure, namely the Sennwald rock avalanche, occurred in the southeast wall of this fold-and-thrust structure due to the rock failure of Lower Cretaceous Helvetic limestones along the Rhine River valley. In this research, this palaeolandslide is examined in a multidisciplinary approach for the first time with detection and mapping of avalanche deposits, dynamic run-out modelling and cosmogenic nuclide dating. During the rock failure, the avalanche deposits were transported down the hillslope in a spreading-deck fashion, roughly preserving the original stratigraphic sequence. The distribution of landslide deposits and surface exposure age of the rock failure support the hypothesis that the landslide was a single catastrophic event. The ${ }^{36} \mathrm{Cl}$ surface exposure age of avalanche deposits indicates an age of $4.3 \pm 0.5 \mathrm{ka}$. This time coincides with a notably wet climate period, noted as a conditioning factor for landslides across the Alps in the mid-Holocene. The contemporaneity of our event at its location in the Eastern Alps provide additional support for the contention of increased regional seismic activity in mid-Holocene.
\end{abstract}

Keywords: Sennwald rock avalanche; cosmogenic nuclide dating; run-out modelling

\section{Introduction}

The Sennwald landslide is a rock avalanche associated with the Lower Cretaceous Helvetic limestones in the southeast wall of the Säntis nappe along the Rhine River valley. Similar catastrophic events constantly reshape the topography and permanently change landscapes, constituting a threat for human life in mountainous terrains such as the European Alps [1-4]. Understanding the patterns, triggering factors and failure mechanisms of landslides is a challenge, particularly for palaeolandslides as they exhibit insufficient topographic evidence to detect the fingerprints of landsliding [5]. It is well-known today that several factors can provide favourable conditions for slope failures and increase in landslide activity regionally, yet the final trigger is often strong ground shaking $[2,6]$, or lengthy wet periods associated with heavy rainfall or storm events [7]. Although individual research on several landslides indicates both climate and seismic triggers, conditioning and triggering factors for landsliding at an Alpine scale are still under debate [7-13]. To address this problem and understand the landslide patterns, more palaeolandslide sites in the Alps such as the Sennwald landslide should be examined with field mapping, geochronological dating techniques and numerical modelling.

In the past decades, various types of landslides with different triggers have been examined with the recent development of age determination techniques [11]. The first dated catastrophic landslide using cosmogenic nuclides was the Koefels landslide in Austria [14,15], and it was followed by the Flims, Switzerland [16], and Fernpass, Austria [17], 
landslides. The investigation of landforms with dating techniques has contributed key aspects in our understanding of spatio-temporal landslide distribution patterns and their interaction with climate change in the Alps $[9,11]$. In particular, dating of mass movements with volumes larger than one million cubic meters using one or a combination of geochronological dating techniques brought a new dimension to the examination of past occurrences and allowed us to forecast future trigger events with respect to their frequency and size [5,11].

Earlier research showed that the inherited rock structure also plays an important role in rock slope stability and occurrence of landslides in various tectonic scales $[18,19]$. The position and geometry of the hillslope, rock type, orientation of bedding and sliding planes with respect to topographic surface and faults also influence the slope failure type and behaviour [20]. Regarding the rock type, high water supply due to heavy rainfall may result in fluid infiltration through faults and fractures [21] particularly in karstic rocks. In rocks affected by karstification, the maximum fluid pressure on the clay and mud permeability barrier on the sliding plane might generate gravitational catastrophic failures [7]. Understanding the structural complexity and geology of slope failure therefore is of great importance for modelling such occurrences with better accuracy. The modelling of such rock failures should be supported with meticulous reporting of field mapping data of both release and deposition areas. Mapping of landslide-related morphological features such as toma hills or the distribution pattern of landslide deposits in the deposition area is another key aspect in landslide research. A toma (i.e., cone-shaped hill) is a typical hill structure at various sizes made of landslide deposits and commonly seen in rock avalanche related events in the Alps [22]. Identifying such geomorphological features provides useful information in establishing landsliding patterns on a regional scale.

In landslides, both the release and deposition areas, and hillslope morphology are irreversibly affected in different ways depending on whether the landslide is triggered by storm and rainfall events, or earthquakes [23]. The permanent change in the topography can be identified for bedrock landslides triggered by different events at an orogen scale $[2,13,23]$. Earlier studies established that the topographic fingerprints of storm- and earthquake-related landslides can be distinguished with respect to the distribution of the landsliding in the hillslope at the time of the failure, whether sliding material clusters at ridge crests, toes of the hillslope or is uniformly distributed in the entire hillslope. Most Alpine landslides have not been investigated in terms of the topographic fingerprint identification for landslides with different triggers including the Sennwald landslide.

The Sennwald landslide area has been a site of curiosity for engineers and geologists over the last few decades. This site has been studied by geological companies previously, and they provided a good understanding of the subsurface of the landslide deposition area by borehole data. However, the timing and run-out behaviour of this palaeolandslide were not entirely investigated previously and there is a lack of a comprehensive field mapping. To address some of these open questions, we introduce a multidisciplinary examination of the Sennwald landslide with mapping of the landslide deposits, dynamic run-out modelling using DAN3D and surface exposure dating using cosmogenic ${ }^{36} \mathrm{Cl}$ as well as an analysis of potential triggers and causes of the landslide. We also present the estimated landslide volume and role of the stratigraphic position in slope failure. We believe that including this palaeolandslide in the inventory of Alpine landslides and rock avalanches with volumes larger than one million cubic meters is quite essential, especially with detailed field reporting and age control (i.e., cosmogenic nuclide dating). Additionally, the landscape change in the hillslope and Rhine River valley with respect to erosional processes and landsliding are explained in this work.

\section{Tectonic Setting and Geology}

The Sennwald landslide occurred in the Säntis nappe at the eastern end of the Helvetic nappes, which formed as a result of collision between the European and Adriatic plates [24] (Figure 1). The Helvetic nappe consists of allochthonous sediments on top that were 
overthrust in a northerly direction [25]. The entire nappe system was cut into two nappe systems by a major thrust, namely the Glarus thrust; the upper Glarus known as the Säntis nappe and the lower Glarus nappe [26,27]. The Säntis nappe is a complex fold-and-thrust (i.e., anticline-syncline folding) structure with axial planes dipping dominantly NW-SE in eastern Switzerland (Figure 1). It consists of numerous tectonic discontinuities $[26,28,29]$ that form a range of hillslopes prone to large slope failures. The parallel-striking thrust and detachment faults of this complex structure caused propagation and folding mostly following the same parallel trend as the mountain chain [28]. The internal variety of the nappe structure is also due to the influence of numerous strike-slip faults and thrusts [28].

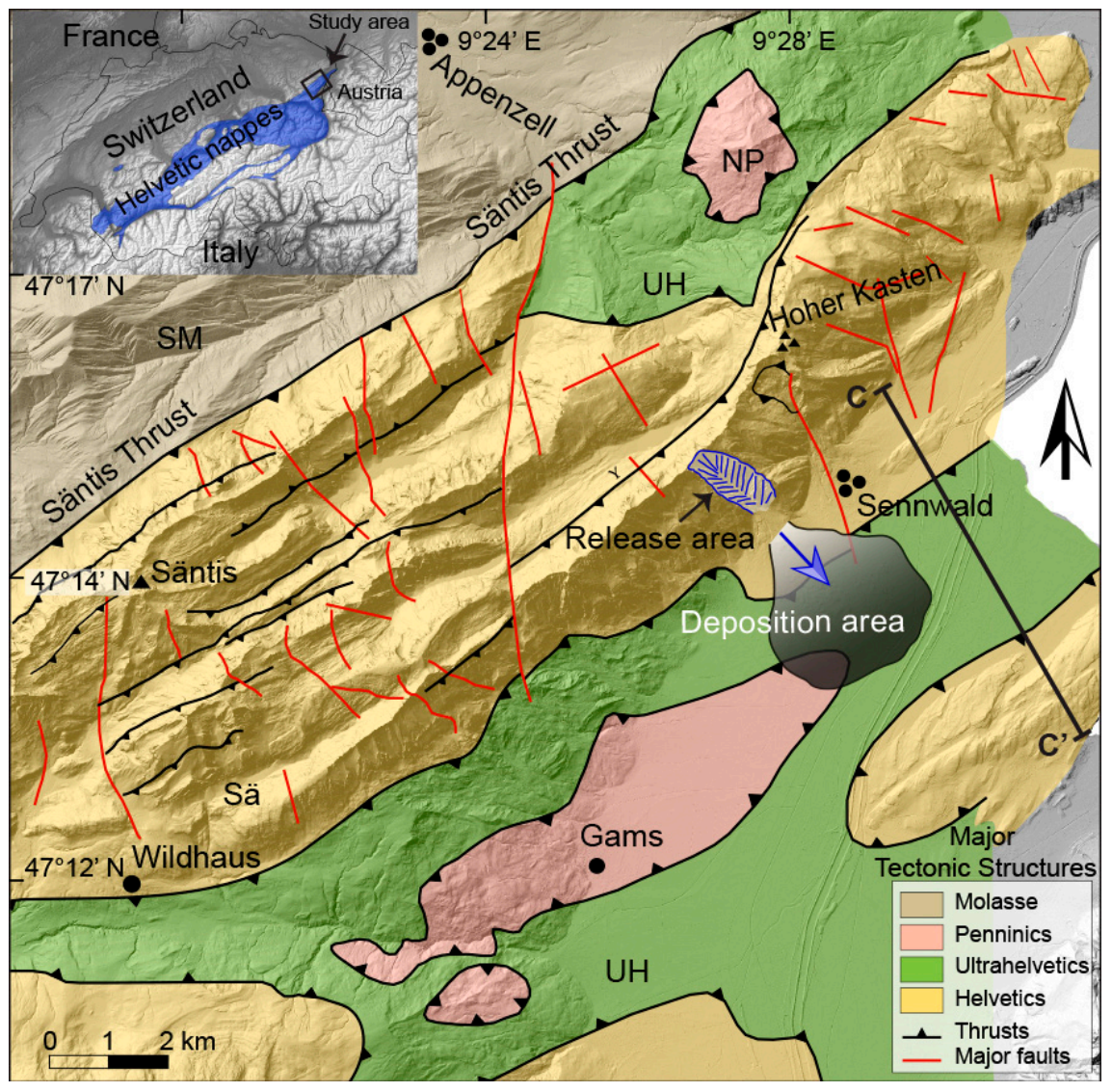

Figure 1. Tectonic map of the Säntis nappe including major tectonic structures and the landslide release and deposition area. Location bar is shown in the top left corner with the Helvetic nappes indicated with blue. Shaded relief image superimposed by a color-coded DEM (swissALTI3D) reproduced with the authorisation of swisstopo (JA100120). The tectonic map is modified following [28].

The release area of the landslide is within the Lower Cretaceous Helvetic limestones. The simplified stratigraphic unit from bottom to top is Vitznau Marl, Betliskalk, Helvetischer Kieselkalk, Drusberg Formation, Schrattenkalk, and Helvetischer Gault. The stratigraphic description of each rock unit in the landslide area is given below.

- Vitznau Marl (Valanginian) [29] consists of mainly marly limestones and is a fossiliferous and clay-rich unit at the base.

- Betliskalk (formerly Valanginienkalk) [29] is mostly bio-pelsparites and biomicrites with fine grain, brownish to greyish and weathered sand with chert nodules. The weathering colour is grey. Betliskalk is stratigraphically on top of Öhrlikalk and Vitznau-Mergel.

- Helvetischer Kieselkalk (Valanginian-Hauterivian) [30,31] consists of siliceous limestone from dark grey to bluish grey colour and is known to be rich in glauconite and pyrite. 
It shows a mixture of calcareous particles, calcified sponge spicules and detrital quartz in a matrix of micritic to microsparitic calcite.

- Drusberg Formation (Barremian) consists of dark blue-grey calcareous shales regularly alternating with thin-bedded light-brownish limestones. Drusberg layers represent autochthonous fauna that consists of sponge spicules, echinoderm fragments and some radiolarians [32]. Oysters and other bivalves, ammonites and nautilids are also noted [33].

- Schrattenkalk (Early Barremian-Early Aptian) [34] is a grey to light grey marine limestone with bioclastic wackestone-packstone, and well-sorted grainstones. Coral, rudist, Nerinea, brachiopod, Porifera, Orbitolinid, echinoid, bivalve and brachiopod are noted in Schrattenkalk [33]. In some parts, detrital quartz and sometimes brecciated lithoclasts are seen in this formation.

- Helvetischer Gault (Late Aptian-Middle Cenomanian), Reference [29], also known as Garschella Formation, consists of greenish to greyish glauconitic sandstones, marls and nodular and sparitic carbonates. Ammonoids, bivalve, belemnite, nautilids, brachiopods and planktonic foraminifera are identified.

\section{The Sennwald Landslide}

\subsection{The Release and Deposition Areas}

The examination of the release and deposition areas in the landslide site was conducted with field mapping supported by the GIS analysis using high resolution $(2 \mathrm{~m} \pm 0.5$ resolution) swissALTI3D digital elevation models, local geological map of the Säntis sheet of the Swiss Geological Atlas Nr. 78 with explanatory notes [35,36] and literature [26,28]. The analysis of the stratigraphy and rock structure was also made available to provide an insight to demonstrate the failure type of the landslide [37-40].

The cross section of the inherited rock structure shows that the dip angle of the bedding plane of limestone units in the release area varies between $50-65^{\circ} \mathrm{SE}$, and each unit is parallel to each other (Figure 2). The dip angle of the sliding plane is also $50^{\circ} \mathrm{SE}$, which is almost parallel to the bedding plane. The parallel position of the bedding and sliding planes to the surface topography is a major component that works for the favour of slope failure as shown in Figure 2.

The landslide material covers an area of about $6 \mathrm{~km}^{2}$ on the alluvial plain along the Rhine River valley (Figure 3). Landslide boulders and blocks of different rock units from the Lower Cretaceous Helvetic limestone are identified at various dimensions at different locations in the landslide deposition site (Figure 4); $2 \times 2 \times 1 \mathrm{~m}^{3}$ being the smallest and $9 \times 8 \times 7 \mathrm{~m}^{3}$ the largest boulder. Most of them are covered with lichen and vegetation (Figure 4). As mentioned in the introduction, several hill-like structures, namely toma, are also observed in several locations in the alluvial terrace [41-43] (Figure 4). Tomas are thought to have formed due to the interaction of the spreading moving mass with the substrate in Alpine rock avalanche events. A wet alluvial substrate, as here in the Rhine River plain, is especially conducive to the formation of such extensional surface features [22].

Sediments of the post-failure ongoing erosional activity on the hillslope cover most of the deposition area today. Soft sediments and loose material were continuously transported from the mountain slope since the failure event forming alluvial fans and gullies at the toe of the hillslope. Forestation and vegetation dominate the general landscape in the entire landslide deposition area as well as swamps in places. Fourteen samples from limestone boulders in the deposition area were collected during the field mapping for lithological analysis and ${ }^{36} \mathrm{Cl}$ surface exposure dating (Figure 5). Further explanation on sampling and sample processing is given in "surface exposure dating using cosmogenic nuclide ${ }^{36} \mathrm{Cl}^{\text {" section. }}$ 


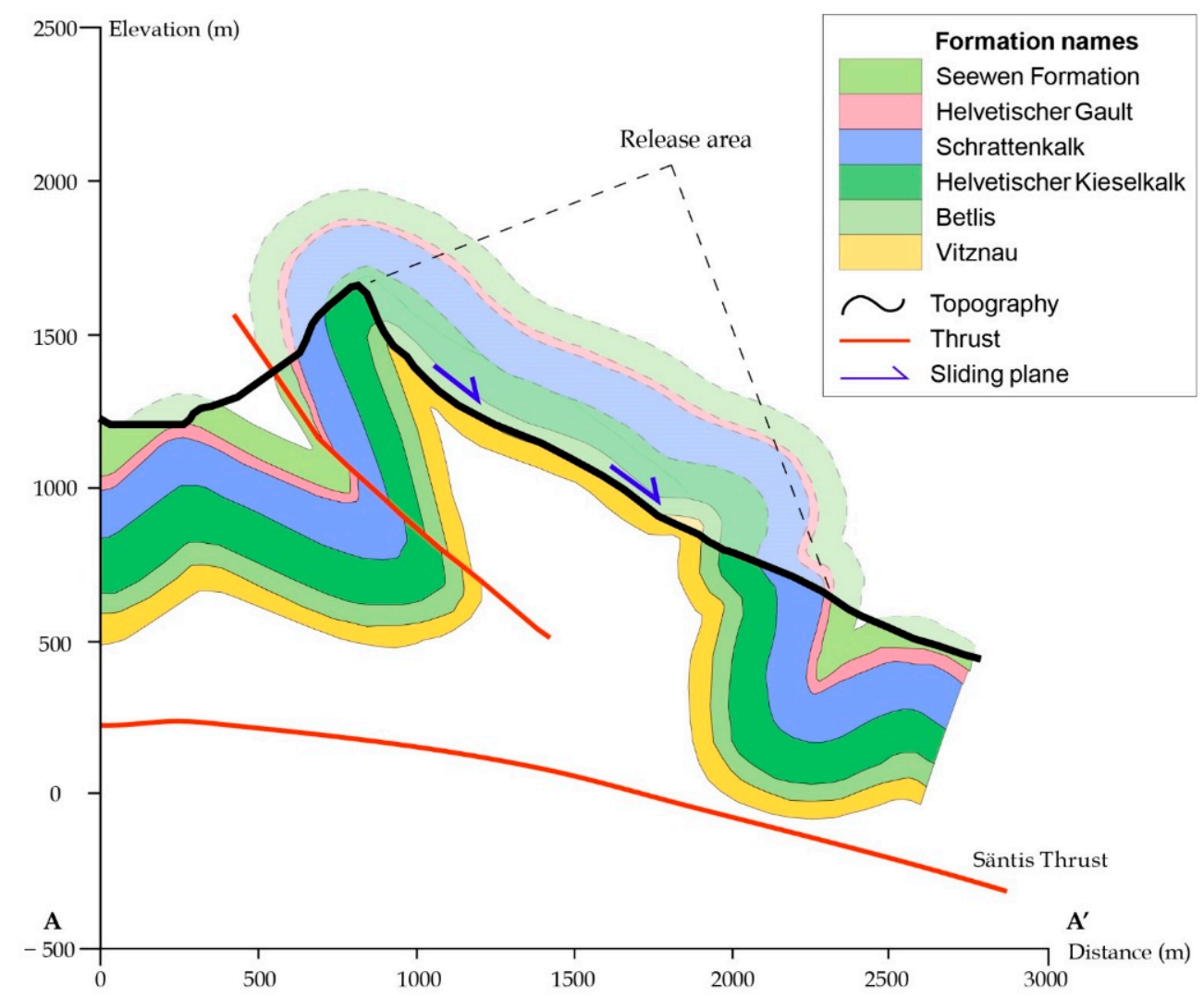

Figure 2. Cross section across the southern wall of the Säntis nappe showing the sliding plane of the Sennwald landslide (modified from [28]). Cross section line $\left(A-A^{\prime}\right)$ is shown in the Surface Map.

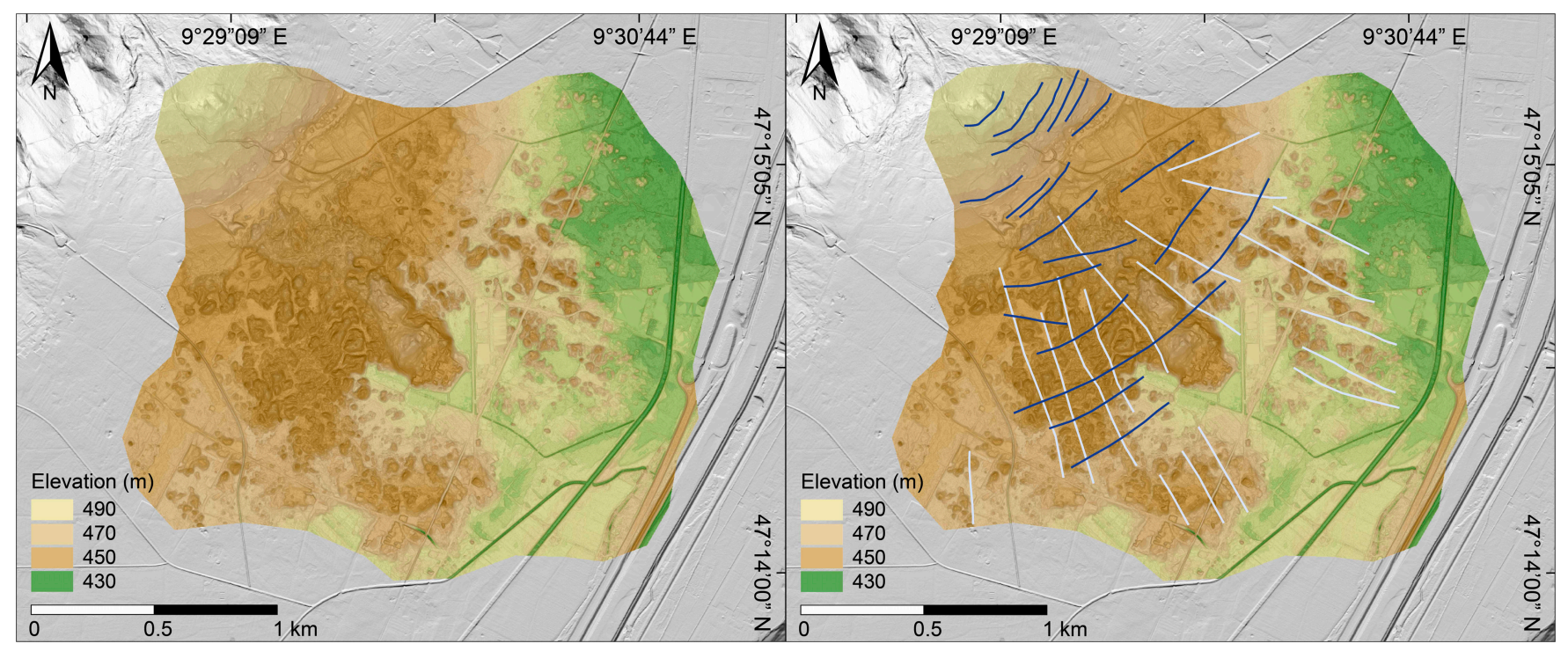

(a)

(b)

Figure 3. (a) Deposition area of the Sennwald landslide (green-brown) shown in detail on a shaded black and white relief image of Sennwald. (b) Transverse (blue lines) and linear (white lines) ridges indicate flow patterns. Shaded relief image superimposed by a color-coded DEM 15 (swissALTI3D) reproduced with the authorisation of swisstopo (JA100120). 


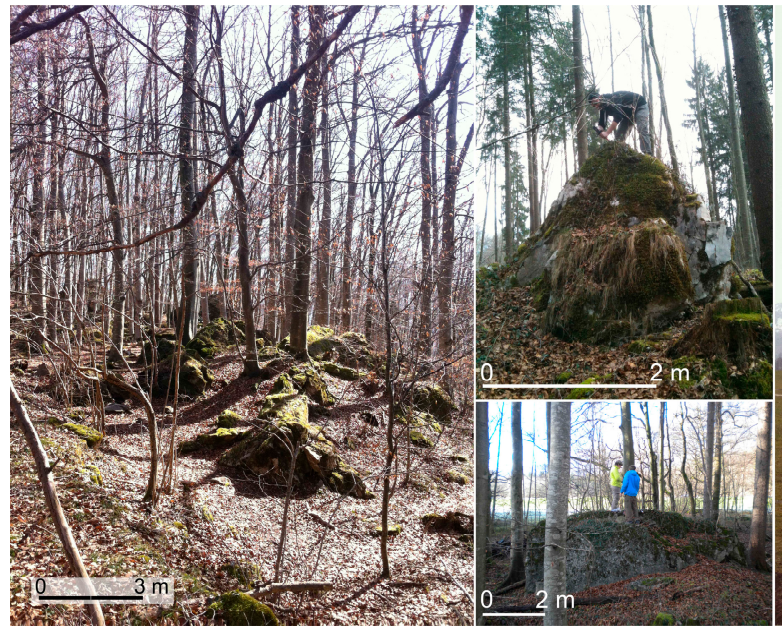

(a)

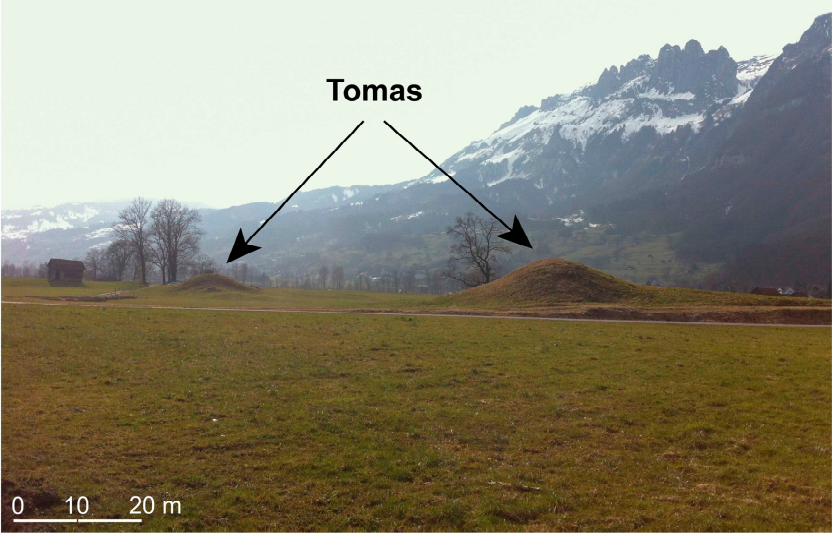

(b)

Figure 4. Field photos showing landslide boulders of various size and surface features in the landslide deposition area. (a) Left: $47^{\circ} 15^{\prime} 29 \mathrm{~N}-9^{\circ} 29^{\prime} 03 \mathrm{E}, 559 \mathrm{~m}$ a.s.l., photo direction: $241^{\circ}$. Left top: Sample SW-13: $47^{\circ} 14^{\prime} 39.02 \mathrm{~N}-9^{\circ} 29^{\prime} 30.02 \mathrm{E}$, $442 \mathrm{~m}$ a.s.l., photo direction: $210^{\circ}$, boulder dimension: $2 \times 3 \times 1 \mathrm{~m}$. Left bottom: Sample SW- 1 : $47^{\circ} 15^{\prime} 05.72 \mathrm{~N}-9^{\circ} 29^{\prime} 54.74 \mathrm{E}$, $443 \mathrm{~m}$ a.s.l., Boulder dimension: $2 \times 7 \times 3 \mathrm{~m}$. (b) Tomas located on the southwestern side of the landslide deposition area. $47^{\circ} 14^{\prime} 63.38 \mathrm{~N}-309^{\circ} 29^{\prime} 10.33 \mathrm{E}, 447 \mathrm{~m}$ a.s.l., photo direction: $210^{\circ}$.

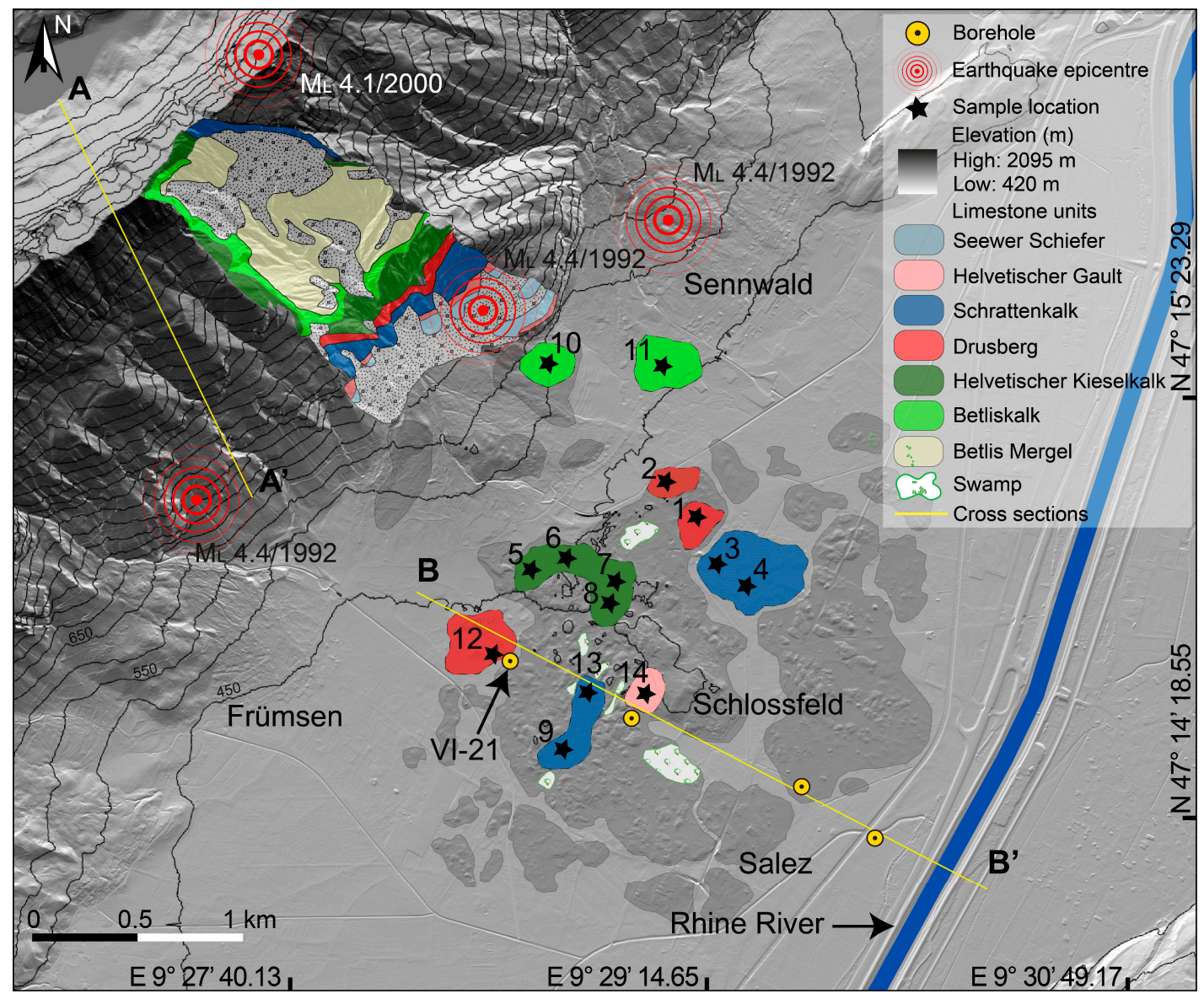

Figure 5. Surface map showing landslide deposits (grey), the dominant boulder lithologies in each sector (blue, yellow, red, green and pink) in the deposition area and the sampling locations (black asterisks indicated with sample numbers). Moderate earthquake epicentres (red asterisks) are also indicated. Altitude is given by colour code. Shaded relief image of the Sennwald region superimposed by a color-coded DEM (swissALTI3D) reproduced by the permission of Swisstopo. 


\subsection{Distribution of the Landslide Material in the Deposition Area}

A comprehensive lithological identification of limestone units was necessary to understand the post-failure distribution pattern of these units in the landslide deposition area. The identification of different limestone units was made based on the textural properties of each limestone unit with hand specimens in the field and thin sections under the microscope (Figure 6). The textural and lithological properties are correlated with the published data in the literature for cross validation (also see "tectonic setting and geology" section). The examination of thin sections and hand specimens shows that five limestone units were involved in the rock failure, namely (stratigraphically from bottom to top), Betliskalk, Kieselkalk, Drusberg, Schrattenkalk and Helvetischer Gault (Figures 2 and 5).

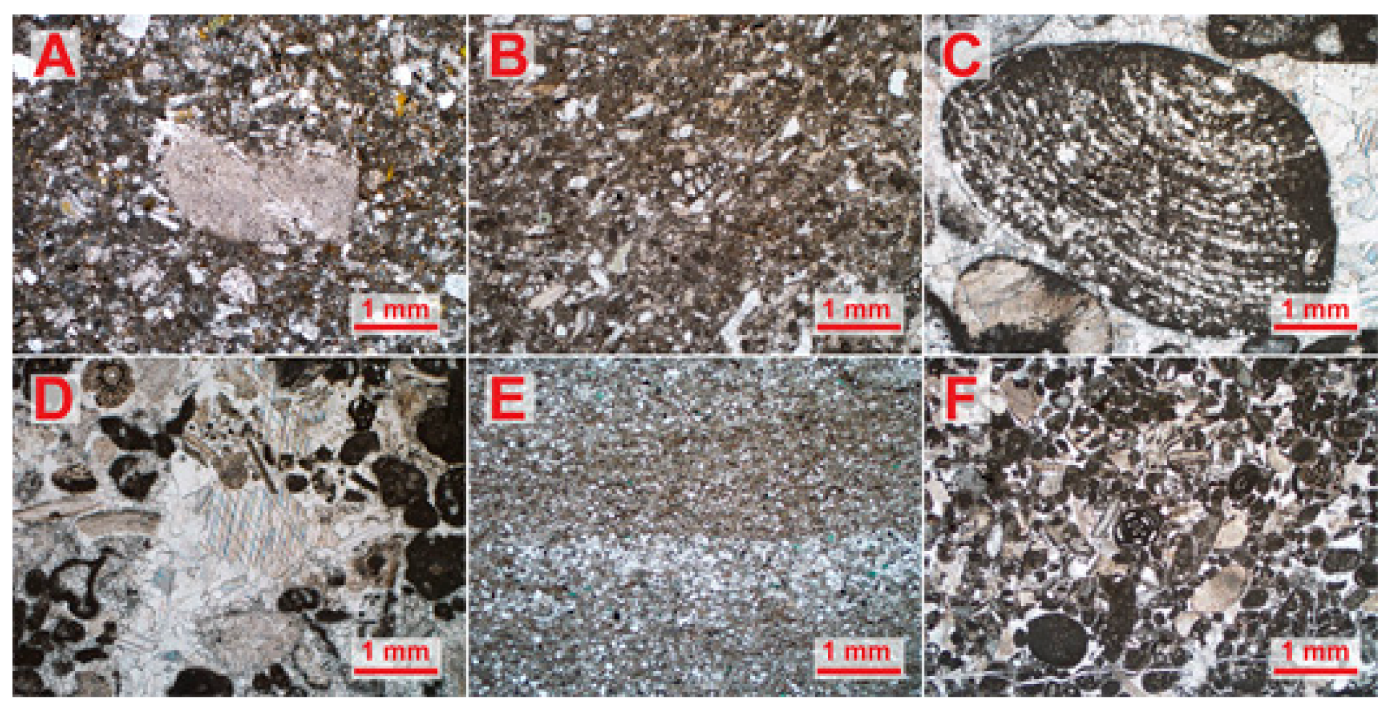

Figure 6. Selection of thin sections from landslide deposits (A) Drusberg, sample no: SW-1. (B) Drusberg, SW-2. (C) Schrattenkalk, SW-3. (D) Schrattenkalk, SW-4. (E) Helvetischer Kieselkalk, SW-7. (F) Schrattenkalk, SW-9. See also text.

Based on field observations, landslide deposits form radial and linear hills (i.e., longitudinal ridges) in plan view in the deposition area (Figure 3) (also see [12,44]). The linear hills are orientated radial and transverse to the direction of the flow. Hills range up to $5-10 \mathrm{~m}$ in height above the general ground surface. Further, the landslide material deposited in a spreading-deck fashion, preserving the original stratigraphic positions between strata [45]. Blocks from stratigraphically the top layer (i.e., Schrattenkalk) in the rock formation travelled the farthest, and blocks derived from stratigraphically the lowest layer (i.e., Betliskalk) travelled the least during the landslide. This release pattern results from shearing along boundaries between geological units (e.g., zones of weakness). This information provides a good understanding for the slope failure pattern and distribution of the landslide material.

The spreading-deck distribution of the landslide deposits might also indicate a single and rapid failure. If the failure would have occurred in multiple events, limestones of various lithological units would form an irregularly distributed mass of lithologies in the deposition area rather than forming a pattern preserving the original stratigraphic position after the failure. Some irregularly distributed smaller rock bodies of different limestone lithologies are found in the landslide deposition site, which might contradict the spreading-deck distribution style hypothesis of the landslide material. However, this might be due to the rapid movement of the rock mass which entangled and dragged relatively smaller limestone blocks of different lithologies. 


\subsection{Cross Profiles for the Release and Deposition Areas}

Previously produced cross section of the landslide deposition area based on borehole data [46] shows earlier depositional environments in the landslide deposition area (Figure 7). These data provide useful information for our understanding of the past landscape and sediment transport dynamics from the hillslope to the valley as well as the impact of landsliding on reshaping the topography.

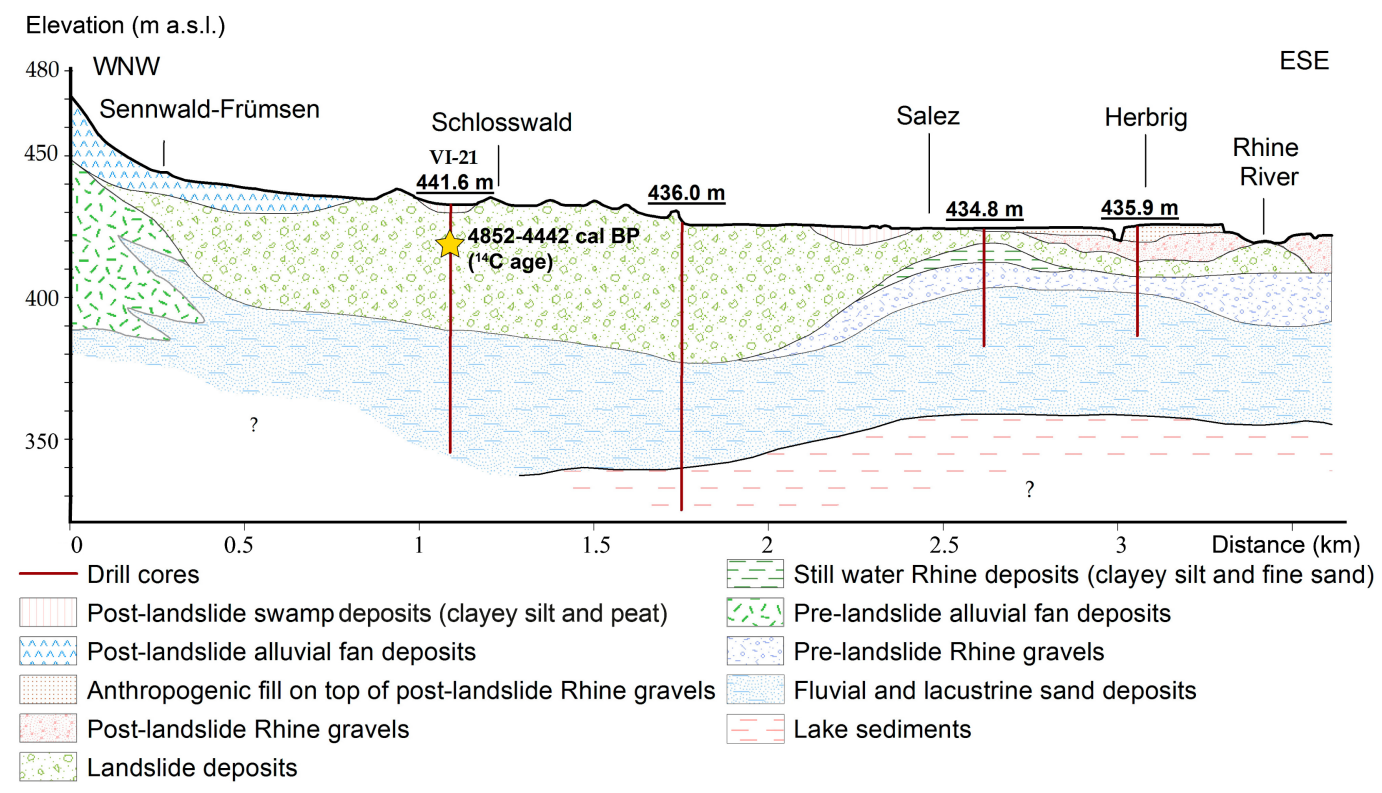

Figure 7. Cross section of the landslide deposition area. Cross section line (B-B') and boreholes are shown in Figure 5. Modified after [46].

After slope failure, the rapid mass movement in Sennwald changed the morphology of the Rhine River valley as landslide deposits ploughed into the existing pre-landslide Rhine gravels and fluvial/lacustrine sediments. Similar events, where landslide deposits block river valleys and change fluvial regimes, are addressed with case studies in the literature $[47,48]$. Consequently, the river channel shifted towards E-SE, which enabled post-landslide Rhine gravels to be deposited along the present-day riverbank and the channel (Figure 7).

As shown in the cross section, the debris spreads over fluvial and lacustrine sediments during the landslide event. Afterwards, younger fluvial sediments continuously accumulated on landslide deposits around the present-day valley channel. These marked fluvial fluctuations below and above the landslide deposits indicate an ongoing sediment discharge and load levels of the Rhine River for that time. The slope material (i.e., alluvial fan and debris flow) both below and above the landslide deposits indicates preand post-failure ongoing erosional processes (i.e., annual sediment transfer via mountain creeks). The borehole data indicates some sediments with unknown thickness of lacustrine environment below the fluvial and lacustrine sediments, possibly indicating that the valley floor used to be lacustrine environment with transitions to delta and fluvial environments before the landslide event. This information is also consistent with suggested palaeo-lake and -river levels of Quaternary valleys in northern and eastern Switzerland [49].

Extensive work to reconstruct the shape of the overdeepened valleys in the Swiss Alps, formed during the course of glacial/interglacial cycles, provides a good overview of solid rock surface-Quaternary cover boundaries [50,51]. Despite the lack of seismic reflection data in the Sennwald area [52,53], the bedrock surface-Quaternary cover boundary (i.e., depth of the rock surface) for the Sennwald area along the Rhine valley is fairly well-known based on both the reconstructions mentioned above (Figure 8). The geological cross section, which shows the complexity of the rock structure, was made available based on the local 
geological map, the Säntis sheet of the Swiss Geological Atlas No. 78 [35,36]. As shown in the geological cross section and indicated in those overdeepening reconstructions, the bedrock in the region of the landslide is $10-50 \mathrm{~m}$ below the ground surface.

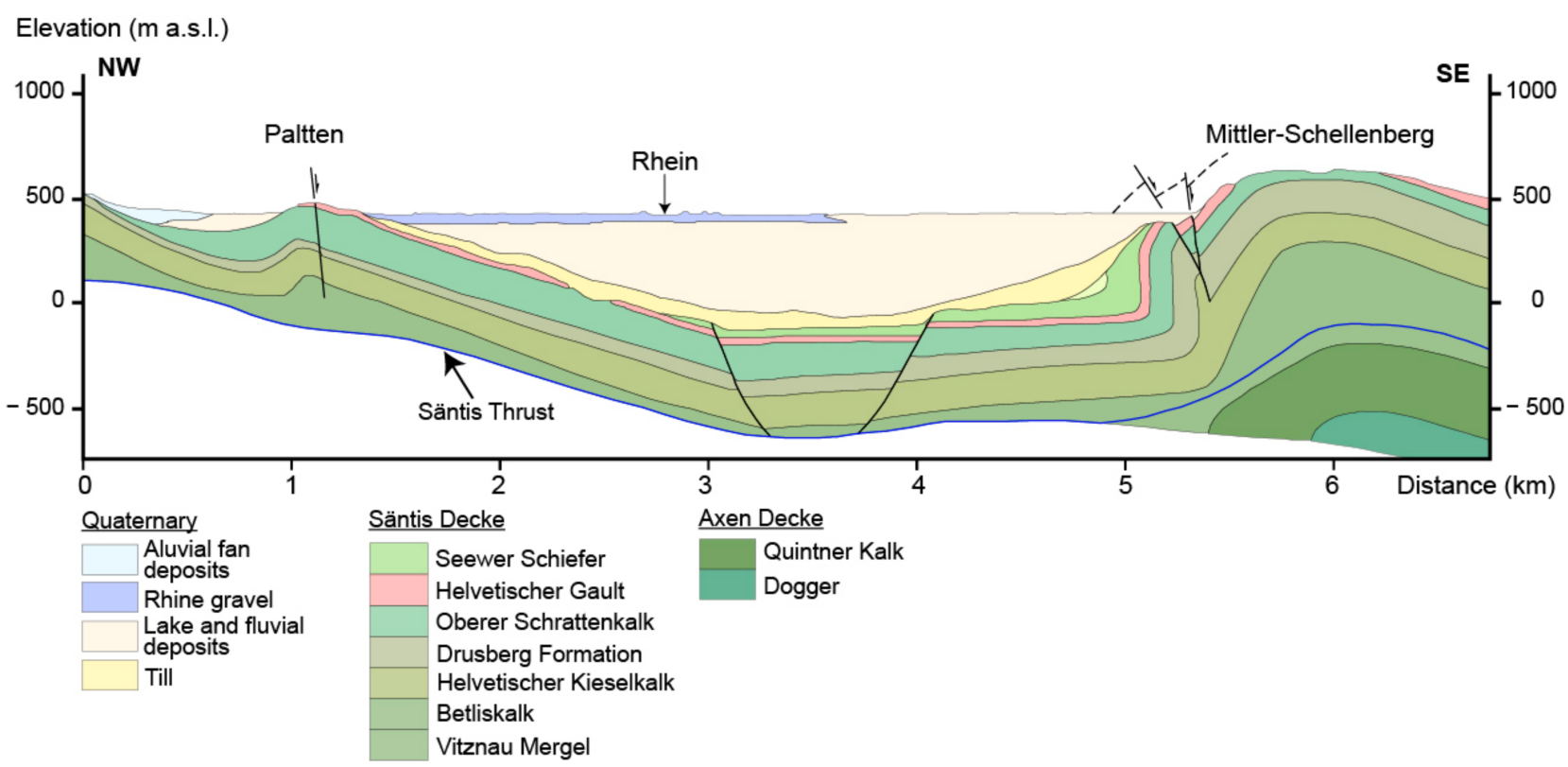

Figure 8. Säntis geological cross section-bedrock surface and Quaternary deposits boundary. Cross section line C-C' is shown in Figure 1. Modified after [36].

\section{Surface Exposure Dating Using Cosmogenic ${ }^{36} \mathrm{Cl}$}

Sampling locations for cosmogenic nuclide dating (Figure 5) were chosen uniformly in the deposition area to evaluate the surface exposure age distribution of landslide boulders. Following the sampling with criterion given by Ivy-Ochs and Kober (2008) [54], samples were prepared as suggested by Ivy-Ochs et al. (2004) [55]. Total $\mathrm{Cl}$ and ${ }^{36} \mathrm{Cl}$ were determined at ETH AMS facility with isotope dilution methods as suggested in the literature [56]. The ETH internal standard $\mathrm{K} 381 / 4 \mathrm{~N}$ with a value of $17.36 \times 10^{-12}$ is used to normalise ${ }^{36} \mathrm{Cl} /{ }^{35} \mathrm{Cl}$ ratios, and the stable ${ }^{37} \mathrm{Cl} /{ }^{35} \mathrm{Cl}$ ratios are standardised to the natural ${ }^{37} \mathrm{Cl} /{ }^{35} \mathrm{Cl}$ ratio $31.98 \%$ [57,58]. Surface exposure ages are calculated with a numerical code [59]. The production rate of $54 \pm 3.5^{36} \mathrm{Cl}$ atoms $\mathrm{g}(\mathrm{Ca})^{-1} \mathrm{yr}^{-1}$ defined for limestones, with a muon contribution of $9.6 \%$, is used for exposure age calculations [60,61]. We used a surface erosion rate for karstified limestones of $0.5 \mathrm{~cm} / \mathrm{ka}$ for all samples [62-64].

$\mathrm{Cl}$ concentrations vary between $4.45 \mathrm{ppm}$ and $19.56 \mathrm{ppm}$ as shown in Table 1. These are rather low total $\mathrm{Cl}$ concentration values, which means that the production of ${ }^{36} \mathrm{Cl}$ was dominantly from $\mathrm{Ca}$. Thus, the low energy neutron capture ${ }^{36} \mathrm{Cl}$ production pathway was negligible. The elemental analysis (XRF) is performed to reveal the trace and major element concentrations, and thus the influence of major and trace elements to ${ }^{36} \mathrm{Cl}$ production. The results of XRF analysis also show that trace element concentrations are not significant in ${ }^{36} \mathrm{Cl}$ production in our samples (see Appendix A Table A1). Samples SW-5, 6, 7 and 8 (i.e., rocks of Helvetischer Kieselkalk) showed no reaction with the $2 \mathrm{M}$ nitric acid $\left(\mathrm{HNO}_{3}\right)$. Therefore, these four samples were not considered for further procedure. 
Table 1. AMS-measured ${ }^{36} \mathrm{Cl}$ concentrations and exposure ages with error margins for the Sennwald landslide.

\begin{tabular}{|c|c|c|c|c|c|c|c|}
\hline $\begin{array}{l}\text { Sample } \\
\text { Code }\end{array}$ & $\begin{array}{c}\text { Elevation } \\
(\mathrm{m})\end{array}$ & Latitude & Longitude & Shielding & $\begin{array}{c}{ }^{36} \mathrm{Cl} \mathrm{10} \\
\text { Atoms/g Rock }\end{array}$ & $\begin{array}{c}\mathrm{Cl} \text { in Rock } \\
(\mathrm{ppm})\end{array}$ & $\begin{array}{c}\text { Exposure Ages } \\
\text { (Years) }\end{array}$ \\
\hline SW-1 & 443 & 47.2516 & 9.4985 & 0.992 & $0.112 \pm 0.015$ & $4.5 \pm 0.1$ & $3850 \pm 520$ \\
\hline SW-2 & 446 & 47.2530 & 9.4970 & 0.991 & $0.065 \pm 0.005$ & $19.6 \pm 0.2$ & $2340 \pm 120$ \\
\hline SW-4 & 439 & 47.2484 & 9.5017 & 0.985 & $0.151 \pm 0.008$ & $9.7 \pm 0.2$ & $5030 \pm 310$ \\
\hline SW-9 & 445 & 47.2415 & 9.4900 & 0.990 & $0.197 \pm 0.012$ & $13.6 \pm 0.3$ & $6480 \pm 440$ \\
\hline SW-10 & 503 & 47.2582 & 9.4910 & 0.980 & $0.140 \pm 0.007$ & $13.1 \pm 0.2$ & $4360 \pm 260$ \\
\hline SW-12 & 446 & 47.2458 & 9.4858 & 0.990 & $0.114 \pm 0.006$ & $11.5 \pm 0.2$ & $3770 \pm 220$ \\
\hline SW-13 & 442 & 47.2442 & 9.4917 & 0.990 & $0.130 \pm 0.007$ & $16.0 \pm 0.2$ & $4210 \pm 260$ \\
\hline SW-14 & 443 & 47.2439 & 9.4952 & 0.990 & $0.142 \pm 0.007$ & $15.5 \pm 0.2$ & $4440 \pm 250$ \\
\hline
\end{tabular}

The mean ${ }^{36} \mathrm{Cl}$ surface exposure age is $4.3 \mathrm{ka}$ with a mean error margin $\pm 0.5 \mathrm{ka}$. Calculated ages show a uniform distribution in the deposition area with similar ages ranging from $3.7 \mathrm{ka}$ to $5.0 \mathrm{ka}$ except for two samples. Sample SW-2 reveals a relatively shorter exposure age, $2.3 \pm 0.1 \mathrm{ka}$, whereas sample SW-9 reveals a longer exposure age, $6.5 \pm 0.4 \mathrm{ka}$. SW-9, Helvetischer Gault stratigraphically the top layer, was possibly exposed to cosmic rays previously due to its position on the hillslope before the rock failure. The surface exposure age of sample SW-10, Betliskalk (stratigraphically bottom layer), is $4.4 \pm 0.3 \mathrm{ka}$. This indicates that samples (except for SW-2 and 9) show similar surface exposure ages regardless of their (i) distribution in the deposition area and (ii) original stratigraphic position on the hillslope. The similarity of exposure ages provides support for the hypothesis that the Sennwald landslide was a single rock failure.

The mean surface exposure age is also in agreement with the ${ }^{14} \mathrm{C}$ age, $4150 \pm 80{ }^{14} \mathrm{C}$ yr [65], which we calibrated using OxCal online v4.2.4 [66,67]. Our calibration of ${ }^{14} \mathrm{C}$ ages from previously dated wood pieces taken from the 21-21.5 m depth of borehole VI-21 (for borehole location see Figures 5-7) reveal $4852-4442$ cal BP with $95.4 \%$ probability. The consistency of surface exposure ages and radiocarbon age also supports the single rock failure hypothesis.

\section{Dynamic Run-Out Modelling}

\subsection{Pre-Failure Topography and Volume Estimation}

Reconstruction of the pre-failure topography is a key step for volume estimation and dynamic run-out modelling. Our reconstruction of the pre-failure surface is based on the modern topography in the release and deposition areas with fieldwork observations, thickness estimates from the borehole data and GIS examination. The borehole data and our field measurements show that present-day maximum elevation in the deposition area is $460 \mathrm{~m}$ a.s.l., and the average thickness of the landslide deposits is ca. $35 \mathrm{~m}$ a.s.l., whereas the maximum thickness is ca. $85 \mathrm{~m}$ a.s.l. This shows that the maximum elevation of the prefailure topography in the deposition area in the Rhine Valley was $425 \mathrm{~m}$ a.s.l. Furthermore, using the borehole data, reconstruction of pre-failure elevations and boundaries of the deposition area was made with transitional steps as we adjusted each chosen point based on each neighbouring point accordingly.

For the reconstruction of the pre-failure topography, we estimated the volume of the landslide material by subtracting the reconstructed pre-failure topography from the post-failure (present) topography using the borehole data. The subtraction between the pre- and post-failure topographies reveals the height difference (i.e., deposit thickness). The estimated volume of landslide material in the deposition area is 123 million $\mathrm{m}^{3}$ and 92 million $\mathrm{m}^{3}$ in the release area. About $25 \%$ of fragmentation bulking factor was calculated following the volume estimates for the deposition and release areas. The bulking factor describes the volume increase due to material dispersion or incorporated material during 
the run-out on a rock failure and is often suggested to be between $25-30 \%$ for similar rock movements [68-70].

\subsection{Run-Out Simulation}

The numerical run-out modelling is performed for the Sennwald landslide using a dynamic simulation modelling software, namely DAN3D, which is generated for mass movements such as landslides and debris flows [71]. DAN3D is a well-tested tool used for constructing landslide events by simulating the landslide material like a flowing rock avalanche [70,72-76]. The software works on the basis of certain inputs such as the elevation and rheology of rock [71]. The purpose of dynamic modelling is to understand the run-out behaviour, acquire and compare landslide deposit thickness with our estimates and confirm our single rock failure hypothesis.

Parameters used for the landslide simulation following criteria in the literature (References therein [70]) have been listed alongside the modelling results in Table 2. We assumed a unit weight of $24 \mathrm{kN} \mathrm{m}^{-3}$ for limestone to perform the modelling in DAN3D. Rheology parameters such as the internal friction angle (which affects the degree of the spreading material) and the friction angle (which represents the basal flow resistance) have been adjusted by trial-and-error to find the best fit for the total run-out distance and lateral spreading of the landslide material in the deposition area [77]. We set the basal friction angle to $16^{\circ}$ and internal friction angle $30^{\circ}$ after numerous trial runs. The basal friction angle that we applied is within the range of commonly used values for rock avalanches on the basis of earlier research [73,77] (also see [70]).

Table 2. Parameters used for run-out simulation and results.

\begin{tabular}{cc}
\hline Parameter & Value \\
\hline Release volume & $92 \times 10^{6}\left(\mathrm{~m}^{3}\right)$ \\
\hline Deposition area & $6\left(\mathrm{~km}^{2}\right)$ \\
\hline Unit weight for limestone & $24.0\left(\mathrm{kN} / \mathrm{m}^{3}\right)$ \\
\hline Internal friction angle & $35\left({ }^{\circ}\right)$ \\
\hline Coefficient of friction & 0.25 \\
\hline Mean velocity & $50(\mathrm{~m} / \mathrm{s})$ \\
\hline Max-min thickness & $60-20(\mathrm{~m})$ \\
\hline Plan travel distance & $1611(\mathrm{~m})$ \\
\hline Total emplacement time & $150(\mathrm{~s})$ \\
\hline
\end{tabular}

Figure 9 shows the visual run-out modelling results of selected time-steps with simulated deposit thicknesses and landslide deposition area. The landslide run-out direction is to the southeast. The duration of the simulated run-out is $150 \mathrm{~s}$. The maximum velocity is $93 \mathrm{~m} / \mathrm{s}$, and mean velocity is approximately $50 \mathrm{~m} / \mathrm{s}$. From the top of the hillslope to the farthest point that landslide deposits reached is $4500 \mathrm{~m}$.

The mean deposit thickness retrieved from the simulation, $24 \mathrm{~m}$ a.s.l., is within the expected range of present-day mean thickness in the deposition area measured from the borehole data. Although, the observed mean deposit thickness spatially varies in the deposition area and is slightly greater than the simulated deposit thickness. The thickness variation in observed deposits could be explained by inherited pre-existing morphological features of the pre-landslide topography and estimated bulking factor (i.e., 25\%). Additionally, simulated deposits show a more evenly distributed pattern, since DAN3D simulates landslide deposits like a whole flowing material. To partially justify these differences, simulated and estimated velocities have been compared. The minimum velocity $\left(v_{\text {min }}\right)$ required to reach the observed runup height $(h)$ has been estimated following the equation below [78]: 


$$
v_{\min }=\sqrt{ }(2 g h)
$$

where $g$ is gravitational acceleration, and $h$ is the observed maximum deposits thickness ( $h=85 \mathrm{~m}$ ). Our estimated $v_{\min }$ is $41 \mathrm{~m} / \mathrm{s}$, which agrees well with the simulated model velocity of $50 \mathrm{~m} / \mathrm{s}$. This shows that the simulated velocity and deposit thickness are consistent with our predicted model and observed thickness.
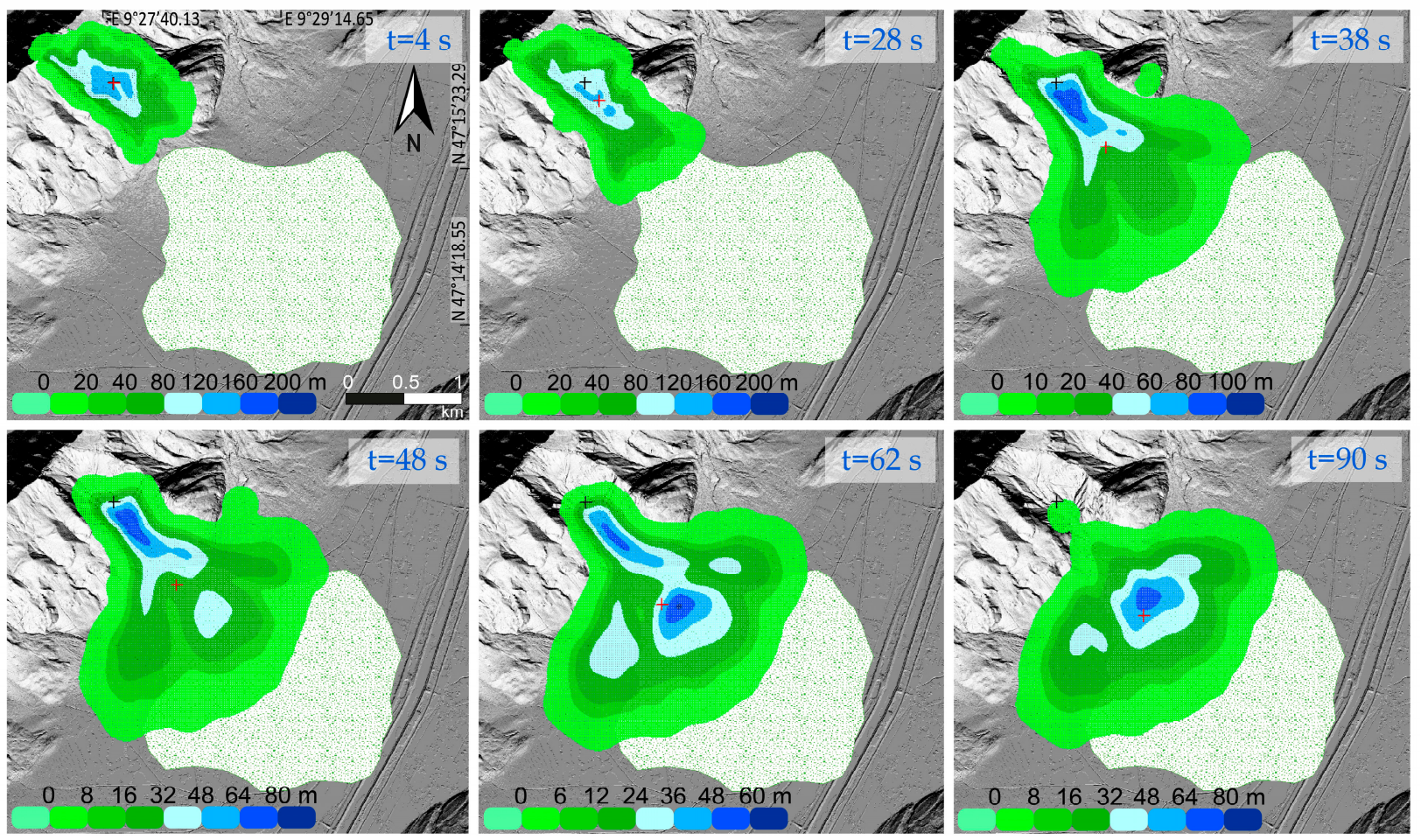

Figure 9. Dynamic run-out modelling showing the thickness of landslide deposits with selected time steps. The dotted area indicated the landslide deposition area determined using DEM in support of field observations. DAN3D numerical modelling code after [71,73].

The lateral spreading of simulated landslide deposits does not entirely resemble the field observations in given time-steps in Figure 9. This difference between the simulated and observed extents is partly due to the bulking factor. DAN3D does not take the bulking factor into account for simulation. Therefore, the spread in the present-day topography is greater than the simulated results. Additionally, there were artefact deposits that move independently from the defined run-out path in the simulation particularly after $90 \mathrm{~s}$ (also see [76]). Therefore, only representative visual results have been shown in Figure 9. These artefacts are due to the adjustable parameters (e.g., stiffness coefficient, margin cut-off thickness) within the code to provide flexibility to modify the simulation until the best fit is found, and they, in fact, do not indicate any change in the volume. Overall, the results of our run-out simulation support the hypothesis of a catastrophic single failure for the Sennwald rock avalanche.

\section{Discussion: Potential Triggers}

Examining the spatio-temporal clustering of landslides of similar size is a key aspect for a better understanding of potential enhancing causes of landslides in the context of Alpine (palaeo)landsliding, such as the Sennwald landslide. Most palaeolandslides in the Alpine setting had previously been associated with the after effects of the last deglaciation (i.e., after around 18,000 years ago) before geochronological dating techniques have been widely used [79]. However, examination of around 40 landslides with dating techniques in the Alps showed that they in fact occurred within two periods; around 11-9 ka year 
(i.e., within the Preboreal period) and around 5-3 ka year (i.e., within the Subboreal period) (Figure 10) [7,12]. In addition, two major climate fluctuations are identified at a European scale: (i) the mostly dry period at $8.2 \mathrm{ka}$ and (ii) the period of long-lasting heavy rainfall at $4.2 \mathrm{ka}$ [80]. Based on ${ }^{36} \mathrm{Cl}$ and ${ }^{14} \mathrm{C}$ data in our work, the Sennwald landslide occurred at $4.3 \pm 0.5 \mathrm{ka}$, which shows a link with this suggested heavy rainfall period. Although there is a debate for the $4.2 \mathrm{ka}$ period as a trigger for mass movements (see [7]), the remote spatial distribution of similar landslide events in various geographical locations in the Alps around this time [12] indicates a climate change influence possibly as a conditioning factor.

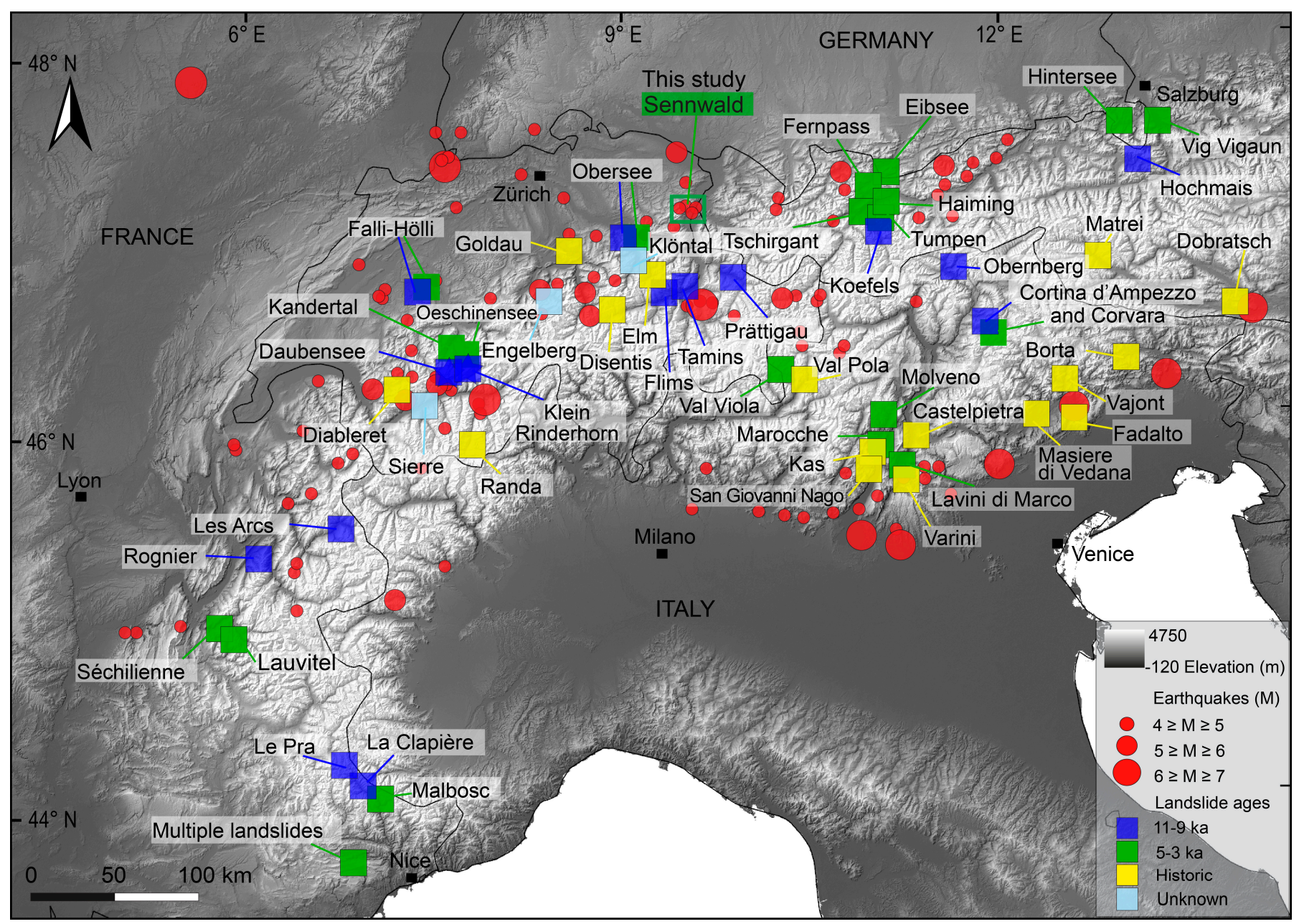

Figure 10. Spatio-temporal distribution of Alpine palaeolandslides shown with instrumental and historical earthquakes epicentres indicated with red circles [81,82]. Circle size indicates the magnitude of the earthquake. Landslides are listed from the oldest to the youngest as follows: around 11-9 ka (blue star): Prättigau 11.5-10.3 ka [83], La Clapiere 10.7-7.1 ka [84,85], Klein Rinderhorn and Daubensee 9.8 ka [70], Koefels 9.5 ka [86], Flims 9.4 ka [87], Tamins 9.4 ka [12], Hochmais 9.3-8.2 [88], Rognier 8.8 ka [89], Obernberg 8.6 ka [90]; around 5-3 ka (green rectangular), Haiming and Vig Vigaun (after [91]), Sechilienne 6.4-0 ka [92], Marocca Principale 5.3 ka [12], Multiple landslides 5.1-3.3 ka [7], Malbosc 5.0-3.0 ka (Braucher, unpublished; from [7]), Lauvitel 4.7 ka [93], Eibsee 4.1 ka [94], Fernpass 4.1 ka [17], Hintersee 3.8 ka [95], Tumpen 3.6 ka [88], Kandertal 3.2 ka [96], Tschirgant 3.0 ka [97], Molveno 4.8 ka [98], Lavini di Marco 3.0-0.8 ka [58], Oeschinensee 2.3 ka [99]; historic landslides (yellow triangle), Matrei, Disentis, Castelpietra, San Giovanni, Masiere di Vedana and Val Pola (after [91]), Fadalto 365 CE [100], Varini 565-970 CE [101], Kas 1100 CE [12], Dobratsch 1348 CE [102], Diableret 1714, 1749 CE, Borta 1692 [103], Goldau 1806 CE, Elm 1881 CE, Vajont 1963 CE, Randa 1991. Multiple events are also shown: Obersee 13.4-5.1, 7.7-3.6 ka [76], Le Pra 12-11, 9-7, 5.0-2.5 ka [104], Les Arcs 11-8.5, 5.5-3.2 ka [105], Cortina and Corvara 10.7-8.4, 8.2-6.9, 5.8-4.5, 4.0-2.1 ka [10], Falli-Hölli 10-9, 5.5-3.2 ka [93]; and landslides with unknown ages (light blue hexagon), Sierre, Engelberg, Klöntal. Hillshade map based on Swisstopo (JA100120). 
In Sennwald, landslide deposits were stratigraphically on top of the Vitznau Marl (i.e., the sliding plane of the landslide), a Valanginian clay-rich limestone-marl alternation [29], on pre-failure state (as indicated in the "tectonic setting and geology" section). Clays are the weakest and most unstable material on slopes at $>10^{\circ}$ angle due to the parallel internal realignment of the clay particles which reduces the internal friction over time. The contact between this unstable barrier and weakened (i.e., karstified) limestone package might have prepared the conditions for a slope failure with the presence of water possibly with heavy rainfall influence. It should be noted that heavy rainfall periods should occur over a long period of time to be considered as a trigger or enhancing factor for such large landslides [10,106]. As pointed out, mid-Holocene climate changes have had significant effects on hydrological processes in Europe [107,108], influencing the European Alps as a trigger or enhancing factor for large landslides [7].

Although spatio-temporal clustering of landslides is well-identified at an Alpine scale, especially with the research on the past few decades, seismic triggers leading to large-scale slope failures remain not fully understood. Earthquakes may influence the slope stability reportedly in a number of ways based on field research in various landslide sites since the 18th century [6]. Earlier research suggested a link between landsliding and periods of increased neotectonic activity in Eastern Alps in the mid-Holocene $[9,13]$. Moreover, it is not impossible to associate palaeolandslides with earthquakes using historical earthquake data or seismic interpretation and core analysis on specific layers in lake sediments (see Figure 10) $[109,110]$. In a recent study, a spatial correlation between large rock avalanches (i.e., Eibsee and Fernpass) and the largest palaeoearthquake imprints recorded in the lakes was made in the Eastern Alps corresponding to $4.1 \pm 0.1 \mathrm{ka} \mathrm{BP} \mathrm{[13].} \mathrm{This} \mathrm{site} \mathrm{is} \mathrm{about}$ $100 \mathrm{~km}$ away from Sennwald. In fact, moderate earthquakes occur around Sennwald even today (Figure 5) [111,112]. The earthquake catalogue [81,82] shows several moderate earthquakes $\left(M_{L}=4-5\right)$ with 5-10 km depth associated with the Säntis Thrust in Sennwald (Figures 5 and 10). The spatio-temporal contemporaneity of the Sennwald landslide with other palaeolandslides in the Eastern Alps support our hypothesis for an earthquaketriggered landslide.

The inherited rock structure plays an important role in rock slope stability and occurrence of rock slides as shown in earlier research $[18,19]$. The position of the hillslope, orientation of bedding and sliding planes and lithological differences may also contribute to the rock failure in various mountainous settings. The vulnerability to fragmentation has mostly been observed in large earthquake-related areas with thrusting, and it especially increases in slopes located on the hanging wall of fault systems [113]. The landslide material in Sennwald similarly originated from the hanging wall (Figure 2) of the Säntis thrust during the rock failure. The seismic shaking most likely caused the reduction of the frictional strength along the southeast dipping sliding plane (i.e., almost parallel to the southeast dipping hillslope) in the hanging wall. Therefore, it was crucial to examine the rock structure and geology with meticulous field mapping for a better understanding of our landslide event.

Furthermore, examining the topographic fingerprints of landslides is of importance to understand landsliding patterns and map palaeolandslides with far greater accuracy and in far greater numbers by using topographic as well as image data. Previous studies statistically examined topographic fingerprints of various landslides associated with climate and earthquake triggers on hillslopes, and they identified different patterns for storm and seismic shaking related events [2]. For example, as mentioned in the introduction, it is suggested that slope failures related to permafrost degradation would have high elevation release areas [114,115], whereas earthquake-triggered landslides may have their bedrock niche along ridge crests (seismic amplification) rather than down in the slope [23]. Heavy precipitation related landslides are expected to originate lower down in the slope [23], and rainfall-induced landslides may originate from the entire slope [2]. These landslidetrigger patterns provide useful insights to distinguish earthquake-triggered landslides from climate-triggered landslides. Our observation on present day topography and analysis 
on the position of rocks in the pre-failure state with respect to surface topography in the hillslope shows that the landsliding was originated in the ridge crest on the entire slope where the susceptibility to slope failure was greatest. This might support our hypothesis that the Sennwald landslide was possibly linked to heavy rainfall as an enhancing factor in a period of increased earthquake activity.

\section{Conclusions}

This research is a multidisciplinary examination of a palaeolandslide-related surface change in the southeast slope of the Säntis nappe in eastern Switzerland. The detailed investigation of the time, failure and run-out behaviour of the Sennwald palaeolandslide in this overdeepened Alpine valley are presented for the first time in this work.

Our analysis indicates that the orientation of the bedding and sliding planes worked in the favour of rock failure in Sennwald. Surface exposure ages, performed using cosmogenic nuclide ${ }^{36} \mathrm{Cl}$ from eight samples in the landslide deposition area, reveal that the rock failure occurred in the mid-Holocene with the calculated mean age of $4.3 \pm 0.5 \mathrm{ka}$. The radiocarbon dating age, ca. 4.9-4.4 ka cal BP, supports the surface exposure age of the rock failure. The numerical 3D simulation of the landslide, made based on estimated volume, slope angle and friction angle, shows that $92 \times 10^{6} \mathrm{~m}^{3}$ of material moved down the slope in $150 \mathrm{~s}$. The landslide material travelled ca. $2000 \mathrm{~m}$ with a maximum velocity of $93 \mathrm{~m} / \mathrm{s}$ and currently covers an area of about $6 \mathrm{~km}^{2}$ in the deposition area.

The spreading-deck-like release mechanism of the landslide material with almost preserved stratigraphy, results of the DAN3D simulation and the uniform distribution of surface exposure ages in the deposition area support the single-failure hypothesis. The topographic fingerprint of the Sennwald landslide points out earthquake and heavy rainfall influence. Coincidentally, the time of the rock failure corresponds to the increased neotectonic activity in Eastern Alps, which increases our confidence for the hypothesis that the Sennwald landslide was associated with earthquake activity during a heavy rainfall period.

Author Contributions: Conceptualization, S.A. and S.I.-O.; methodology, S.A, S.I.-O., K.H., L.G. and C.V.; validation, S.A., S.I.-O., K.H., L.G. and C.V.; formal analysis, S.A. and S.I.-O.; investigation, S.A. and S.I.-O.; resources, S.I.-O.; data curation, S.A.; writing-original draft preparation, S.A.; writing-review and editing, S.A., S.I.-O., K.H. and L.G.; visualization, S.A.; supervision, S.I.-O.; project administration, S.I.-O.; funding acquisition, S.I.-O. All authors have read and agreed to the published version of the manuscript.

Funding: Fieldwork, laboratory work and AMS measurements were funded by the Laboratory of Ion Beam Physics, ETH Zürich.

Institutional Review Board Statement: Not applicable.

Informed Consent Statement: Not applicable.

Data Availability Statement: The authors declare that the data supporting the findings of this study are available within the article.

Acknowledgments: All members of the Ion Beam Physics group of ETHZ, led by Arno Synal, are thanked for their support of this work, especially those who did shifts during the measurements. We thank Peter Zwahlen for sharing his unpublished ${ }^{14} \mathrm{C}$ dating data taken from boreholes in the Sennwald area.

Conflicts of Interest: The authors declare no conflict of interest. 


\section{Appendix A}

Table A1. XRF results for chemical compounds with LOI corrected values and trace elements with LOI corrected values used in the age calculations.

\begin{tabular}{|c|c|c|c|c|c|c|c|c|}
\hline Sample & SW-1 & SW-2 & SW-4 & SW-9 & SW-10 & SW-12 & SW-13 & SW-14 \\
\hline $\mathrm{SiO}_{2}$ & 1.32419 & 11.614 & 0.69853 & 0.86071 & 0.8894 & 0.71356 & 1.1239 & 1.36607 \\
\hline $\mathrm{TiO}_{2}$ & 0.00909 & 0.02581 & 0.01176 & 0.00905 & 0.00905 & 0.00846 & 0.0085 & 0.0161 \\
\hline $\mathrm{Al}_{2} \mathrm{O}_{3}$ & 0.09483 & 0.58497 & 0.09747 & 0.09896 & 0.09505 & 0.10379 & 0.08502 & 0.24805 \\
\hline $\mathrm{Fe}_{2} \mathrm{O}_{3}$ & 0.75522 & 0.35147 & 0.10195 & 0.1295 & 0.14201 & 0.16358 & 0.13262 & 0.1437 \\
\hline $\mathrm{MnO}$ & 0.01249 & 0.00983 & 0.0028 & 0.00509 & 0.00679 & 0.00395 & 0.00397 & 0.00477 \\
\hline $\mathrm{MgO}$ & 0.26518 & 0.46577 & 0.29073 & 0.55647 & 0.47695 & 0.38245 & 0.47098 & 0.4973 \\
\hline $\mathrm{CaO}$ & 54.896 & 48.0414 & 55.3741 & 55.383 & 55.4178 & 55.5288 & 55.3443 & 57.7568 \\
\hline $\mathrm{Na}_{2} \mathrm{O}$ & 0.09767 & 0.02458 & 0.01008 & 0.02092 & 0.03621 & 0.01072 & 0.05214 & 0.01491 \\
\hline $\mathrm{K}_{2} \mathrm{O}$ & 0.02385 & 0.14624 & 0.01568 & 0.02036 & 0.02207 & 0.01861 & 0.02154 & 0.05188 \\
\hline $\mathrm{P}_{2} \mathrm{O}_{5}$ & 0.00738 & 0.02581 & 0.01008 & 0.01357 & 0.01075 & 0.01015 & 0.017 & 0.00716 \\
\hline $\mathrm{Cr}_{2} \mathrm{O}_{3}$ & 0 & 0 & 0 & 0 & 0 & 0 & 0 & 0.00012 \\
\hline $\mathrm{NiO}$ & 0.00137 & 0.00127 & 0.00113 & 0.00096 & 0.0011 & 0.00133 & 0.00125 & 0.00122 \\
\hline LOI & 43.7522 & 38.4559 & 44.4527 & 43.8691 & 43.8288 & 44.0069 & 43.77 & 40.6972 \\
\hline Total & 101.239 & 99.7471 & 101.067 & 100.968 & 100.936 & 100.952 & 101.031 & 100.805 \\
\hline B & 0.00000 & 0.00000 & 0.00000 & 0.00000 & 0.00030 & 0.00030 & 0.00030 & 0.00030 \\
\hline $\mathrm{Sm}$ & 0.00000 & 0.00000 & 0.00000 & 0.00000 & 0.00006 & 0.00006 & 0.00004 & 0.00004 \\
\hline $\mathrm{Gd}$ & 0.00000 & 0.00000 & 0.00000 & 0.00000 & 0.00006 & 0.00006 & 0.00005 & 0.00005 \\
\hline $\mathrm{U}$ & 0.00000 & 0.00000 & 0.00000 & 0.00000 & 0.00040 & 0.00040 & 0.00050 & 0.00050 \\
\hline Th & 0.003210 & 0.003310 & 0.003940 & 0.003490 & 0.000020 & 0.000020 & 0.000050 & 0.000050 \\
\hline
\end{tabular}

\section{References}

1. Stark, C.P.; Hovius, N. The characterization of landslide size distributions. Geophys. Res. Lett. 2001, 28, 1091-1094. [CrossRef]

2. Meunier, P.; Hovius, N.; Haines, J.A. Topographic site effects and the location of earthquake induced landslides. Earth Planet. Sci. Lett. 2008, 275, 221-232. [CrossRef]

3. Korup, O. Earth's portfolio of extreme sediment transport events. Earth-Sci. Rev. 2012, 112, 115-125. [CrossRef]

4. Davies, T. Landslide Hazards, Risks, and Disasters: Introduction; Elsevier Inc.: Amsterdam, The Netherlands, 2015; ISBN 9780123964755.

5. Malamud, B.D.; Turcotte, D.L.; Guzzetti, F.; Reichenbach, P. Landslide inventories and their statistical properties. Earth Surf. Process. Landf. 2004, 29, 687-711. [CrossRef]

6. Keefer, D.K. Investigating landslides caused by earthquakes-A historical review. Surv. Geophys. 2002, 23, 473-510. [CrossRef]

7. Zerathe, S.; Lebourg, T.; Braucher, R.; Bourlès, D. Mid-Holocene cluster of large-scale landslides revealed in the Southwestern Alps by 36Cl dating. Insight on an Alpine-scale landslide activity. Quat. Sci. Rev. 2014, 90, 106-127. [CrossRef]

8. Corsini, A.; Marchetti, M.; Soldati, M. Dinamica olocenica dei versanti nell'area di Corvara in Badia (Dolomiti, Italia): Cronologia e significato paleoclimatico di alcuni fenomeni franosi. Geogr. Fis. E Din. Quat. 2001, 24, 127-139.

9. Prager, C.; Zangerl, C.; Brandner, R.; Patzelt, G. Increased rockslide activity in the middle Holocene? New evidence from the Tyrolean Alps (Austria). In Landslides and Climate Change: Challenges and Solutions; Taylor \& Francis: Oxford, UK, 2007; pp. 25-34.

10. Borgatti, L.; Soldati, M. Landslides as a geomorphological proxy for climate change: A record from the Dolomites (northern Italy). Geomorphology 2010, 120, 56-64. [CrossRef]

11. Pánek, T. Recent progress in landslide dating: A global overview. Prog. Phys. Geogr. 2014, 39, 168-198. [CrossRef]

12. Ivy-Ochs, S.; Martin, S.; Campedel, P.; Hippe, K.; Alfimov, V.; Vockenhuber, C.; Andreotti, E.; Carugati, G.; Pasqual, D.; Rigo, M.; et al. Geomorphology and age of the Marocche di Dro rock avalanches (Trentino, Italy). Quat. Sci. Rev. 2017, 169, 188-205. [CrossRef]

13. Oswald, P.; Strasser, M.; Hammerl, C.; Moernaut, J. Seismic control of large prehistoric rockslides in the Eastern Alps. Nat. Commun. 2021, 12. [CrossRef] 
14. Ivy-Ochs, S.; Heuberger, H.; Kubik, P.; Kerschner, H.; Bonani, G.; Frank, M.; Schlüchter, C. The age of the Köfels event. Relative, 14C and cosmogenic isotope dating of an early Holocene landslide in the Central Alps (Tyrol, Austria). Z. Für Gletsch. Und Glazialgeol. 1998, 34, 57-68.

15. Kubik, P.W.; Ivy-Ochs, S.; Masarik, J.; Frank, M.; Schlüchter, C. 10Be and 26Al production rates deduced from an instantaneous event within the dendro-calibration curve, the landslide of Köfels, Ötz Valley, Austria. Earth Planet. Sci. Lett. 1998, 161, 231-241. [CrossRef]

16. Ivy-Ochs, S.; Poschinger, A.V.; Synal, H.A.; Maisch, M. Surface exposure dating of the Flims landslide, Graubünden, Switzerland. Geomorphology 2009, 103, 104-112. [CrossRef]

17. Prager, C.; Ivy-Ochs, S.; Ostermann, M.; Synal, H.-A.; Patzelt, G. Geology and radiometric 14C-, 36Cl- and Th-/U-dating of the Fernpass rockslide (Tyrol, Austria). Geomorphology 2009, 103, 93-103. [CrossRef]

18. Moore, J.R.; Sanders, J.W.; Dietrich, W.E.; Glaser, S.D. Influence of rock mass strength on the erosion rate of alpine cliffs. Earth Surf. Process. Landf. 2009, 34, 1339-1352. [CrossRef]

19. Stead, D.; Wolter, A. A critical review of rock slope failure mechanisms: The importance of structural geology. J. Struct. Geol. 2015, 74, 1-23. [CrossRef]

20. Ambrosi, C.; Crosta, G.B. Valley shape influence on deformation mechanisms of rock slopes. Geol. Soc. Spec. Publ. 2011, 351, 215-233. [CrossRef]

21. Sweeting, M.M. Karst Landforms; Columbia University Press: New York, NY, USA, 1973.

22. Prager, C.; Zangerl, C.; Nagler, T. Geological controls on slope deformations in the Köfels rockslide area (Tyrol, Austria). Austrian J. Earth Sci. 2009, 102, 4-19.

23. Densmore, A.L.; Hovius, N. Topographic fingerprints of bedrock landslides. Geology 2000, 28, 371-374. [CrossRef]

24. Pfiffner, O.A. The Helvetic nappe system and landscape evolution of the Kander. Bull. Fuer Angew. Geol. 2010, $15,53-61$.

25. Pfiffner, A.O. Geology of the Alps, 2nd ed.; John Wiley \& Sons: Sussex, UK, 2014; ISBN 978-1-118-70812-5.

26. Pfiffner, A. Fold-and-thrust tectonics in the Helvetic Nappes (E Switzerland). Thrust Nappe Tectonics. Geol. Soc. Lond. 1981, 319-327. [CrossRef]

27. Pfiffner, O.A. The structure of the Helvetic nappes and its relation to the mechanical stratigraphy. J. Struct. Geol. 1993, 15, 511-521. [CrossRef]

28. Sala, P.; Pfiffner, O.A.; Frehner, M. The Alpstein in three dimensions: Fold-and-thrust belt visualization in the Helvetic zone, eastern Switzerland. Swiss J. Geosci. 2014, 107, 177-195. [CrossRef]

29. Burger, H.; Strasser, A. Lithostratigraphische Einheiten der untersten Helvetischen Kreide in der Zentral- und Ostschweiz. Eclogae Geol. Helv. 1981, 74, 529-560.

30. Funk, H. Typusprofile der helvetischen Kieselkalk-Formation und der Altmann-Schichten. Eclogae Geol. Helv. 1969, 62, 191-203.

31. Funk, H. The origin of authigenic quartz in the Helvetic Siliceous Limestone (Helvetischer Kieselkalk), Switzerland. Sedimentology 1975, 22, 299-306. [CrossRef]

32. Staeger, D. Geologie der Wilerhorngruppe zwischen Brienz und Lungern. Eclogae Geol. Helv. 1944, 37/1, 99-188.

33. Kursteiner, P. Field Guide to the excursions. In Proceedings of the 9th International Symposium, Cephalopods-Present and Past; Christian Klug, W.E., Ed.; Paläontologisches Institut und Museum, Universität Zürich: Zurich, Switzerland, 2014.

34. Ziegler, M.A. A Study of the Lower Cretaceous Facies Developements in the Helvetic Border Chain, North of the Lake of Thun (Switzerland). Eclogae Geol. Helv. 1967, 60, 509-527.

35. Eugster, H.; Forrer, M.; Frohlicher, H.; Kempf, T.; Schlatter, L.; Blaser, R.; Funk, H.; Langenegger, H.; Spoerri, M.; Habicht, K. Säntis (map sheet 1115) Geological Atlas of Switzerland 1:25.000; Federal Office of Topography (Swisstopo): Bern, Switzerland, 1982.

36. Funk, H.; Habicht, K.J.; Hantke, R.; Pfiffner, A.O. Blatt 1115 Säntis—Geologischer Atlas der Schweiz 1:25'000, Erläuterungen 78; Bundesamt für Wasser und Geologie: Bern, Switzerland, 2000.

37. Gutiérrez-Santolalla, F.; Acosta, E.; Ríos, S.; Guerrero, J.; Lucha, P. Geomorphology and geochronology of sackung features (uphill-facing scarps) in the Central Spanish Pyrenees. Geomorphology 2005, 69, 298-314. [CrossRef]

38. Cossart, E.; Braucher, R.; Fort, M.; Bourlès, D.L.; Carcaillet, J. Slope instability in relation to glacial debuttressing in alpine areas (Upper Durance catchment, southeastern France): Evidence from field data and 10Be cosmic ray exposure ages. Geomorphology 2008, 95, 3-26. [CrossRef]

39. Audemard, F.A.; Beck, C.; Carrillo, E. Deep-seated gravitational slope deformations along the active Boconó Fault in the central portion of the Mérida Andes, western Venezuela. Geomorphology 2010, 124, 164-177. [CrossRef]

40. Pánek, T.; Tábořík, P.; Klimeš, J.; Komárková, V.; Hradeckỳ, J.; Št'astnỳ, M. Deep-seated gravitational slope deformations in the highest parts of the Czech Flysch Carpathians: Evolutionary model based on kinematic analysis, electrical imaging and trenching. Geomorphology 2011, 129, 92-112. [CrossRef]

41. Furrer, G.; Fitze, P. Beitrag zum Permafrostproblem in den Alpen. Vierteljahresschr. Der Nat. Ges. Zürich 1970, 115, $353-368$.

42. Reitner, J.M. Bericht 2000 über geologische Aufnahmen im Quartär auf Blatt 179 Lienz. Jahrb. Der Geol. Bundesanst. 2003, 143, 389-395.

43. Von Poschinger, A. Weitere Erkenntnisse und Weitere Fragen zum Flimser Bergsturz. Bull. Fuer Angew. Geol. $2006,11,35-43$.

44. Dufresne, A.; Davies, T.R. Longitudinal ridges in mass movement deposits. Geomorphology 2009, 105, 171-181. [CrossRef] 
45. Strom, A. Morphology and internal structure of rockslides and rock avalanches: Grounds and constraints for their modelling. In Landslides from Massive Rock Slope Failure; Springer Netherlands: Dordrecht, The Netherlands, 2006; Volume 49, pp. 305-326, ISBN 978-1-4020-4035-1.

46. Kobel, M.; Hantke, R. Zur Hydrogeologie des Rheintales von Sargans bis zum Bodensee (Exkursion E am 19. April 1979). Jahresber. Und Mitt. Des Oberrh. Geol. Ver. 1979, 79-86. [CrossRef]

47. García-García, F.; Sánchez-Gómez, M.; Navarro, V.; Pla, S. Formation, infill, and dissection of a latest-Pleistocene landslidedammed reservoir (Betic Cordillera, Southern Spain): Upstream and downstream geomorphological and sedimentological evidence. Quat. Int. 2011, 233, 61-71. [CrossRef]

48. Korup, O.; Wang, G. Multiple Landslide-Damming Episodes. In Landslide Hazards, Risks and Disasters; Shroder, J.F., Davies, T., Eds.; Elsevier: Amsterdam, The Netherlands, 2015; pp. 241-261, ISBN 9780123964755.

49. Preusser, F.; Reitner, J.M.; Schlüchter, C. Distribution, geometry, age and origin of overdeepened valleys and basins in the Alps and their foreland. Swiss J. Geosci. 2010, 103, 407-426. [CrossRef]

50. Dehnert, A.; Lowick, S.E.; Preusser, F.; Anselmetti, F.S.; Drescher-Schneider, R.; Graf, H.R.; Heller, F.; Horstmeyer, H.; Kemna, H.A.; Nowaczyk, N.R.; et al. Evolution of an overdeepened trough in the northern Alpine Foreland at Niederweningen, Switzerland. Quat. Sci. Rev. 2012, 34, 127-145. [CrossRef]

51. Dürst Stucki, M.; Schlunegger, F. Identification of erosional mechanisms during past glaciations based on a bedrock surface model of the central European Alps. Earth Planet. Sci. Lett. 2013, 384, 57-70. [CrossRef]

52. Pfiffner, A.; Frei, W.; Finckh, P.; Valasek, P. Deep seismic reflection profiling in the Swiss Alps: Explosion seismology results for line NFP 20-East. Geology 1988, 16, 987. [CrossRef]

53. Valasek, P.; Mueller, S.; Frei, W.; Holliger, K. Results of NFP 20 seismic reflection profiling along the Alpine section of the European Geotraverse (EGT). Geophys. J. Int. 1991, 105, 85-102. [CrossRef]

54. Ivy-Ochs, S.; Kober, F. Surface exposure dating with cosmogenic nuclides. Quat. Sci. J. (Eiszeitalt. Und Ggw.) 2008, 57, 179-209. [CrossRef]

55. Ivy-Ochs, S.; Synal, H.A.; Roth, C.; Schaller, M. Initial results from isotope dilution for $\mathrm{Cl}$ and 36Cl measurements at the PSI/ETH Zurich AMS facility. Nucl. Instrum. Methods Phys. Res. Sect. B Beam Interact. Mater. At. 2004, 223-224, 623-627. [CrossRef]

56. Christl, M.; Vockenhuber, C.; Kubik, P.W.; Wacker, L.; Lachner, J.; Alfimov, V.; Synal, H.-A. The ETH Zurich AMS facilities: Performance parameters and reference materials. Nucl. Instrum. Methods Phys. Res. Sect. B Beam Interact. Mater. At. 2013, 294, 29-38. [CrossRef]

57. Synal, H.-A.; Bonani, G.; Döbeli, M.; Ender, R.M.; Gartenmann, P.; Kubik, P.W.; Schnabel, C.; Suter, M. Status report of the PSI/ETH AMS facility. Nucl. Instrum. Methods Phys. Res. Sect. B Beam Interact. Mater. At. 1997, 123, 62-68. [CrossRef]

58. Martin, S.; Campedel, P.; Ivy-Ochs, S.; Viganò, A.; Alfimov, V.; Vockenhuber, C.; Andreotti, E.; Carugati, G.; Pasqual, D.; Rigo, M. Lavini di Marco (Trentino, Italy): 36Cl exposure dating of a polyphase rock avalanche. Quat. Geochronol. 2014, 19, 106-116. [CrossRef]

59. Alfimov, V.; Ivy-Ochs, S. How well do we understand production of 36Cl in limestone and dolomite? Quat. Geochronol. 2009, 4, 462-474. [CrossRef]

60. Stone, J.O.; Allan, G.L.; Fifield, L.K.; Cresswell, R.G. Cosmogenic chlorine-36 from calcium spallation. Geochim. Et Cosmochim. Acta 1996, 60, 679-692. [CrossRef]

61. Stone, J.O.; Evans, J.M.; Fifield, L.K.; Allan, G.L.; Cresswell, R.G. Cosmogenic Chlorine-36 Production in Calcite by Muons. Geochim. Et Cosmochim. Acta 1998, 62, 433-454. [CrossRef]

62. Ivy-Ochs, S.; Kerschner, H.; Reuther, A.; Maisch, M.; Sailer, R.; Schaefer, J.; Kubik, P.W.; Synal, H.-A.; Schlüchter, C. The timing of glacier advances in the northern European Alps based on surface exposure dating with cosmogenic $10 \mathrm{Be}, 26 \mathrm{Al}, 36 \mathrm{Cl}$, and $21 \mathrm{Ne}$. Geol. Soc. Am. Spec. Pap. 2006, 415, 43-60.

63. Häuselmann, P.; Lauritzen, S.-E.; Jeannin, P.-Y.; Monbaron, M. Glacier advances during the last 400 ka as evidenced in St. Beatus Caves (BE, Switzerland). Quat. Int. 2008, 189, 173-189. [CrossRef]

64. Ivy-Ochs, S.; Schaller, M. Chapter 6 Examining Processes and Rates of Landscape Change with Cosmogenic Radionuclides. Radioact. Environ. 2009, 16, 231-294. [CrossRef]

65. Zwahlen, P.; Radiocarbondatierung. Dr. M. Kobel + Partner AG, Büro für Technische Geologie AG, Sargans, Switzerland. Personal communication, 1980.

66. Reimer, P.J.; Austin, W.E.N.; Bard, E.; Bayliss, A.; Blackwell, P.G.; Bronk Ramsey, C.; Butzin, M.; Cheng, H.; Edwards, R.L.; Friedrich, M.; et al. The IntCal20 Northern Hemisphere Radiocarbon Age Calibration Curve (0-55 cal kBP). Radiocarbon 2020, 62, 725-757. [CrossRef]

67. Ramsey, C.B. Bayesian Analysis of Radiocarbon Dates. Radiocarbon 2009, 51, 337-360. [CrossRef]

68. Hungr, O.; Evans, S.G. Entrainment of debris in rock avalanches: An analysis of a long run-out mechanism. Bull. Geol. Soc. Am. 2004, 116, 1240-1252. [CrossRef]

69. Pirulli, M. The Thurwieser rock avalanche (Italian Alps): Description and dynamic analysis. Eng. Geol. 2009, 109, 80-92. [CrossRef]

70. Grämiger, L.M.; Moore, J.R.; Vockenhuber, C.; Aaron, J.; Hajdas, I.; Ivy-Ochs, S. Two early Holocene rock avalanches in the Bernese Alps (Rinderhorn, Switzerland). Geomorphology 2016, 268, 207-221. [CrossRef] 
71. Hungr, O. A model for the runout analysis of rapid flow slides, debris flows, and avalanches. Can. Geotech. J. 1995, 32, 610-623. [CrossRef]

72. Evans, S.G.; Hungr, O.; Enegren, E.G. The Avalanche Lake rock avalanche, Mackenzie Mountains, Northwest Territories, Canada: Description, dating, and dynamics. Can. Geotech. J. 1994, 31, 749-768. [CrossRef]

73. Hungr, O.; Evans, S. Rock avalanche runout prediction using a dynamic model. Landslides 1996, 21.

74. Hungr, O.; Evans, S. A dynamic model for landslides with changing mass. Eng. Geol. Environ. 1997, 41, 719-722.

75. Davies, T.R.; McSaveney, M.J. Runout of dry granular avalanches. Can. Geotech. J. 1999, 36, 313-320. [CrossRef]

76. Nagelisen, J.; Moore, J.R.; Vockenhuber, C.; Ivy-Ochs, S. Post-glacial rock avalanches in the Obersee Valley, Glarner Alps, Switzerland. Geomorphology 2015, 238, 94-111. [CrossRef]

77. Sosio, R.; Crosta, G.B.; Hungr, O. Numerical modeling of debris avalanche propagation from collapse of volcanic edifices. Landslides 2012, 9, 315-334. [CrossRef]

78. Evans, S.G.; Hungr, O.; Clague, J.J. Dynamics of the 1984 rock avalanche and associated distal debris flow on Mount Cayley, British Columbia, Canada; Implications for landslide hazard assessment on dissected volcanoes. Eng. Geol. 2001, 61, 29-51. [CrossRef]

79. Ivy-Ochs, S. Glacier variations in the European Alps at the end of the last glaciation. Cuad. De Investig. Geográfica 2015, 41, 295. [CrossRef]

80. Walker, M.J.C.; Berkelhammer, M.; Björck, S.; Cwynar, L.C.; Fisher, D.A.; Long, A.J.; Lowe, J.J.; Newnham, R.M.; Rasmussen, S.O.; Weiss, H. Formal subdivision of the Holocene Series/Epoch: A Discussion Paper by a Working Group of INTIMATE (Integration of ice-core, marine and terrestrial records) and the Subcommission on Quaternary Stratigraphy (International Commission on Stratigraphy). J. Quat. Sci. 2012, 27, 649-659. [CrossRef]

81. Fäh, D.; Giardini, D.; Kästli, P.; Deichmann, N.; Gisler, M.; Schwarz-Zanetti, G.; Alvarez-Rubio, S.; Sellami, S.; Edwards, B.; Allmann, B.; et al. ECOS-09 Earthquake Catalogue of Switzerland Release 2011. Report and Database -Events from AD 250. Public Catalogue. Swiss Seismological Service ETH Zürich. 2011. Available online: http:/ / ecos09.seismo.ethz.ch/query_sum (accessed on 15 July 2015).

82. USGS ComCat Earthquake Hazards Program. The ANSS Comprehensive Earthquake Catalog (ComCat). Available online: http:/ / earthquake.usgs.gov/earthquakes/search/ (accessed on 20 May 2021).

83. Dapples, F.; Oswald, D.; Raetzo, H.; Lardelli, T.; Zwahlen, P. New records of Holocene landslide activity in the Western and Eastern Swiss Alps: Implication of climate and vegetation changes. Ecol. Geol. Helv. 2003, 96, 1-9. [CrossRef]

84. Bigot-Cormier, F.; Braucher, R.; Bourlès, D.; Guglielmi, Y.; Dubar, M.; Stéphan, J.-F. Chronological constraints on processes leading to large active landslides. Earth Planet. Sci. Lett. 2005, 235, 141-150. [CrossRef]

85. El Bedoui, S.; Bois, T.; Jomard, H.; Sanchez, G.; Lebourg, T.; Trics, E.; Guglielmi, Y.; Bouissou, S.; Chemenda, A.; Rolland, Y.; et al. Paraglacial gravitational deformations in the SW Alps: A review of field investigations, ${ }^{10}$ Be cosmogenic dating and physical modelling. Geol. Soc. Lond. Spec. Publ. 2011, 351, 11-25. [CrossRef]

86. Nicolussi, K.; Spötl, C.; Thurner, A.; Reimer, P.J. Precise radiocarbon dating of the giant Köfels landslide (Eastern Alps, Austria). Geomorphology 2015, 243, 87-91. [CrossRef]

87. von Poschinger, A.; Haas, U. Der Bergsturz von Flims, doch ein warmzeitliches Ereignis. Bull. Für Angew. Geol. 1997, 2, 35-46.

88. Prager, C.; Zangerl, C.; Patzelt, G.; Brandner, R. Age distribution of fossil landslides in the Tyrol (Austria) and its surrounding areas. Nat. Hazards Earth Syst. Sci. 2008, 8, 377-407. [CrossRef]

89. Hippolyte, J.-C.; Brocard, G.; Tardy, M.; Nicoud, G.; Bourlès, D.; Braucher, R.; Ménard, G.; Souffaché, B. The recent fault scarps of the Western Alps (France): Tectonic surface ruptures or gravitational sackung scarps? A combined mapping, geomorphic, levelling, and 10Be dating approach. Tectonophysics 2006, 418, 255-276. [CrossRef]

90. Ostermann, M.; Sanders, D.; Ivy-Ochs, S.; Alfimov, V.; Rockenschaub, M.; Römer, A. Early Holocene (8.6ka) rock avalanche deposits, Obernberg valley (Eastern Alps): Landform interpretation and kinematics of rapid mass movement. Geomorphology 2012, 171-172, 83-93. [CrossRef]

91. Martin, S.; Ivy-Ochs, S.; Viganò, A.; Campedel, P.; Rigo, M.; Vockenhuber, C.; Gabrieli, F.; Mair, V.; Rossato, S. LANDSLIDES OF THE WESTERN DOLOMITES: CASE STUDIES FROM THE ADIGE AND SARCA VALLEYS (NE ITALY). Alp. Mediterr. Quat. 2020, 33, 191-207. [CrossRef]

92. Le Roux, O.; Schwartz, S.; Gamond, J.F.; Jongmans, D.; Bourles, D.; Braucher, R.; Mahaney, W.; Carcaillet, J.; Leanni, L. CRE dating on the head scarp of a major landslide (Séchilienne, French Alps), age constraints on Holocene kinematics. Earth Planet. Sci. Lett. 2009, 280, 236-245. [CrossRef]

93. Delunel, R.; Hantz, D.; Braucher, R.; Bourlès, D.L.; Schoeneich, P.; Deparis, J. Surface exposure dating and geophysical prospecting of the Holocene Lauvitel rock slide (French Alps). Landslides 2010, 7, 393-400. [CrossRef]

94. Jerz, H.; von Poschinger, A. Neuere Ergebnisse zum Bergsturz Eibsee-Grainau. Geol. Bavarica 1995, 99, $383-398$.

95. von Poschinger, A.; Thom, P. Bergsturz Hintersee/Ramsau (Berchtesgadener land): Neue Untersuchungsergebnisse. Quartär Südbayern 1995, 99, 399.

96. Singeisen, C.; Ivy-Ochs, S.; Wolter, A.; Steinemann, O.; Akçar, N.; Yesilyurt, S.; Vockenhuber, C. The Kandersteg rock avalanche (Switzerland): Integrated analysis of a late Holocene catastrophic event. Landslides 2020, 17, 1297-1317. [CrossRef] 
97. Ostermann, M.; Ivy-Ochs, S.; Sanders, D.; Prager, C. Multi-method ( ${ }^{14} \mathrm{C},{ }^{36} \mathrm{Cl},{ }^{234} \mathrm{U} /{ }^{230} \mathrm{Th}$ ) age bracketing of the Tschirgant rock avalanche (Eastern Alps): Implications for absolute dating of catastrophic mass-wasting. Earth Surf. Process. Landf. 2017, 42, 1110-1118. [CrossRef]

98. von Wartburg, J.; Ivy-Ochs, S.; Aaron, J.; Martin, S.; Leith, K.; Rigo, M.; Vockenhuber, C.; Campedel, P.; Viganò, A. Constraining the Age and Source Area of the Molveno landslide Deposits in the Brenta Group, Trentino Dolomites (Italy). Front. Earth Sci. 2020, 8, 164. [CrossRef]

99. Köpfli, P.; Grämiger, L.M.; Moore, J.R.; Vockenhuber, C.; Ivy-Ochs, S. The Oeschinensee rock avalanche, Bernese Alps, Switzerland: A co-seismic failure 2300 years ago? Swiss J. Geosci. 2018, 111, 205-219. [CrossRef]

100. Abele, G. Bergstürze in den Alpen: Ihre Verbreitung. In Morphologie und Folgeerscheinungen, Wissenschaftliche Alpenvereinshefte 25; Deutscher Alpenverein: München, Germany, 1974.

101. Orombelli, G.; Sauro, U. I Lavini di Marco: Un gruppo di frane oloceniche nel contesto morfoneotettonico dell'alta Val Lagarina (Trentino). Suppl. Di Geogr. Fis. E Din. Quat. 1988, 1, 107-116.

102. Brandt, A. Die Bergstürze an der Villacher Alpe (Dobratsch), Kärnten/ Östereich: Untersuchungen zur Ursache und Mechanik der Bergstürze. Ph.D. Thesis, University of Hamburg, Hamburg, Germany, 1981.

103. Bonnard, C. Technical and Human Aspects of Historic Rockslide-Dammed Lakes and Landslide Dam Breaches. Springer: Berlin/Heidelberg, Germany, 2011; pp. 101-122.

104. Sanchez, G.; Rolland, Y.; Corsini, M.; Braucher, R.; Bourlès, D.; Arnold, M.; Aumaître, G. Relationships between tectonics, slope instability and climate change: Cosmic ray exposure dating of active faults, landslides and glacial surfaces in the SW Alps. Geomorphology 2010, 117, 1-13. [CrossRef]

105. Hippolyte, J.-C.; Bourlès, D.; Braucher, R.; Carcaillet, J.; Léanni, L.; Arnold, M.; Aumaitre, G. Cosmogenic 10Be dating of a sackung and its faulted rock glaciers, in the Alps of Savoy (France). Geomorphology 2009, 108, 312-320. [CrossRef]

106. Soldati, M.; Corsini, A.; Pasuto, A. Landslides and climate change in the Italian Dolomites since the Late glacial. In Proceedings of the Catena; Elsevier: Amsterdam, The Netherlands, 2004; Volume 55, pp. 141-161.

107. Simonneau, A.; Chapron, E.; Vannière, B.; Wirth, S.B.; Gilli, A.; Di Giovanni, C.; Anselmetti, F.S.; Desmet, M.; Magny, M. Multidisciplinary distinction of mass-movement and flood-induced deposits in lacustrine environments: Implications for Holocene palaeohydrology and natural hazards (Lake Ledro, Southern Alps, Italy). Clim. Past Discuss. 2012, 8, 3205-3249. [CrossRef]

108. Magny, M.; Combourieu-Nebout, N.; De Beaulieu, J.L.; Bout-Roumazeilles, V.; Colombaroli, D.; Desprat, S.; Francke, A.; Joannin, S.; Ortu, E.; Peyron, O; et al. North-south palaeohydrological contrasts in the central mediterranean during the holocene: Tentative synthesis and working hypotheses. Clim. Past 2013, 9, 2043-2071. [CrossRef]

109. Strasser, M.; Anselmetti, F.S.; Fäh, D.; Giardini, D.; Schnellmann, M. Magnitudes and source areas of large prehistoric norhern Alpine earthquakes revealed by slope failures in lakes. Geology 2006, 34, 1005-1008. [CrossRef]

110. Strasser, M.; Monecke, K.; Schnellmann, M.; Anselmetti, F.S. Lake sediments as natural seismographs: A compiled record of Late Quaternary earthquakes in Central Switzerland and its implication for Alpine deformation. Sedimentology 2013, 60, 319-341. [CrossRef]

111. Calais, E.; Nocquet, J.M.; Jouanne, F.; Tardy, M. Current strain regime in the Western Alps from continuous Global Positioning System measurements, 1996-2001. Geology 2002, 30, 651-654. [CrossRef]

112. Froitzheim, N.; Plasienka, D.; Schuster, R. Alpine tectonics of the Alps and Western Carpathians. Geol. Cent. Eur. 2008, 2, 1141-1232.

113. Brune, J.N. Shattered Rock and Precarious Rock Evidence for Strong Asymmetry in Ground Motions during Thrust Faulting. Bull. Seismol. Soc. Am. 2001, 91, 441-447. [CrossRef]

114. Stoffel, M.; Huggel, C. Effects of climate change on mass movements in mountain environments. Prog. Phys. Geogr. 2012, 36, 421-439. [CrossRef]

115. Deline, P.; Akçar, N.; Ivy-Ochs, S.; Kubik, P.W. Repeated Holocene rock avalanches onto the Brenva Glacier, Mont Blanc massif, Italy: A chronology. Quat. Sci. Rev. 2015, 126, 186-200. [CrossRef] 